\title{
Video Oyunlarında Şiddetin Sunumu Üzerine Bir Araştırma
}

\author{
A Research on the Presentation of Violence in Video Games \\ Ali Arıcı, Dr. Öğr. Üyesi, Bilecik Şeyh Edebali Üniversitesi Bozüyük M.Y.O., E-posta: ali.arici@bilecik.edu.tr \\ Özgür Kılınç, Dr. Öğr. Üyesi, İönü Üniversitesi İletişim Fakültesi, E-posta: ozgur.kilinc@inonu.edu.tr
}

https://doi.org/10.47998/ikad.931792

Anahtar Kelimeler:

Video Oyunlar, Şiddet, Sosyal Öğrenme.

\section{Keywords:}

Video Games, Violence, Social Learning.

\section{$\ddot{O} z$}

Etkileşimli ve eğlence odaklı kültür endüstrisi ürünleri olan video oyunlar, içerdikleri şiddet unsurları ve saldırganlığa kaynaklık edip etmedikleri konusunda tartışılmaktadır. Söz konusu tartışma yeni medya teknolojilerinin sunduğu imkanlar dahilinde yeni nesil video oyunlarla daha da belirginleşmektedir. Bu tartışma zemininde çalışma ile son dönem çıkan veya çıkacak olan yeni nesil video oyunların tanıtım materyalleri şiddet bileşenleri ve örüntüsü bağlamında analiz edilmiştir. Dolayısıyla en çok beklenen 10 video oyun yargısal örneklem ile seçilmiş ve bu oyunların farklı formatlardaki 24 tanıtım videosu betimsel, kategorik ve bağlamsal boyutta incelenmiştir. Analizlerde yeni nesil oyunların genel olarak yetişkinler için üretildiği, bu bakışla şiddeti "satış dili” haline getirdikleri görülmektedir. Oyun tanıtımlarında genel örüntüde ve oranda görünen şiddet anlatısı, alternatif / fantastik evren atmosferinde geçmekte; şiddetin taraflarını ağırlıklı biçimde insan ve insansı varlıklar (antropomorfizm) temsil etmektedir. Öte yandan bu durum şiddetin eylemsel yönünü ortadan kaldırmamakta, şiddet akışı bedensel ve kolektif türde hayata geçmektedir. "Hayatta kalma" ve "topluluk yönetimi" gibi gerekçelerle meşruiyet kazanan şiddet dokusu, "distopya", "kurgusal gerçeklik", "gerilim” ve "teknolojik donanım” gibi bileşenler eşliğinde dolaylı öğrenme bağlamları üretebilmektedir. 


\section{Giriş}

Video oyunları, her biri kendine özgü mekânsallığa sahip sanal dünyalar olup (Shaw ve Warf, 2009: 1332) toplumsal, kültürel ve psikolojik anlamı olan popüler eğlence fenomenleridir (Berger, 2002: 3). Kucklich (2006: 104) dijital oyunların "kültürden kaynaklanan derin kökleri olan kültürel ürünler" olduğunu ifade etmektedir. Söz konusu oyunlar sadece teknolojik değil aynı zamanda kültürel ürünlerdir (Murray, 2018). Dolayısıyla video oyunları içerdiği kültürel ve estetik unsurlardan kaynaklı dikkat çekmektedir (Egenfeldt-Nielsen vd., 2013: 7). Video oyunları belirli bir kültürü temsil eden popüler ürünler olup bu oyunlar çeşitli kültürel kodlar barındırmaktadır.

Video oyunları sadece içerdiği kültürel ve estetik ögeler ile gündeme gelmemektedir. $\mathrm{Bu}$ oyunlar kamuoyunda çeşitli tartışmalara yol açmaktadır. Söz konusu tartışmaların başında video oyunların çeşitli şiddet içeriklerini barındırdığı tartışması gelmektedir. Przybylski vd. (2009: 243) video oyunların medyada ve kültürde büyük bir tartışma yarattığını ve bu tartışmaların birçok popüler video oyununun şiddet temalarına yöneldiği üzerine olduğunu vurgulamaktadır. Şiddet içeren video oyunlarının gençlik saldırganlığ ve şiddetin ciddi eylemleri üzerindeki potansiyel etkisine ilişkin endişeler kamuoyunda, politika yapıcılar arasında ve sosyal bilimciler arasında yıllardır tartışılmaktadır (Ferguson, 2011: 377). Bu oyunların genel olarak şiddeti övdüğü ve anti-sosyal davranışları teşvik ettiği belirtilmektedir (Gunter, 1998: 15).

Video oyunları önemli birer çalışma alanı olup bu oyunların etkileri sosyal ve kültürel hayatın birçok alanını kapsamaktadır (Crawford, 2012: 13). Şiddet kavramı da sosyal hayatın görünür boyutlarından biridir. Bu doğrultuda araştırma video oyunlardaki şiddet içeriklerine odaklanmaktadır. Araştırmanın amacı video oyunlarda şiddetin nasıl kurulduğu ve sunulduğunu incelemektir. Belirlenen amaç doğrultusunda 10 video oyununa ait 24 tanıtım videosu hem açık anlamları yorumlamak hem de örtük anlamları yüzeye taşımak amacıyla nitel içerik analizi yöntemi ile incelenmiştir. Çalışmada öncelikle genel olarak video oyunlarına, ardından video oyunlarında şiddet ile sosyal öğrenme teorisine değinilmektedir. Bahsi geçen kuramsal çerçeveyi ise yöntem, bulgular ve sonuç bölümleri izlemektedir.

\section{Video Oyunları}

Popüler birer eğlence formu olan video oyunları (Gunter, 2016: 20), üretimi yapılan diğer ürünlerden farklılık göstermektedir. Bu ürünler aynı anda elektriksel, mekaniksel ve sanat eseri olmalı; mühendislikten, edebiyatta; sanattan, psikolojiye kadar birçok alandaki fikirleri birleştirmeli ve topluma "oyunun" kültürel bir aracı olmayı sunmalıdır (Iwatani, 2015: ix). Video oyunları, II. Dünya Savaşı sırasında yaygın olarak kullanılan uçuş simülatörlerine kadar uzanan oldukça uzun bir geçmişe sahiptir. 1962'de Steve Russell, ilk video oyunu Spacewar'1 icat etmiştir. Yazılım şirketi Atari, on yıl sonra klasik jetonlu video oyunu Pong'u yayınlayınca video oyunlarının popülerliği gelişmeye başlamıştır (Shaw ve Warf, 2009: 1333). 
Gentile ve Anderson (2003) video oyunlarının tarihi gelişiminin üç döneme ayrılabileceğini öne sürmektedir. 1977 'den 1985 'e kadar olan ilk dönem, piyasaya egemen olan Atari oyun konsollarının adını taşıyan "Atari dönemi" olarak anılmaktadır. $\mathrm{Bu}$ dönemin oyunlarının oldukça mütevazi teknolojik olanaklara sahip olması şiddetin tasvirini zorlaştırmıştır. Bu süre zarfındaki oyunlar oldukça soyut olup çok az şiddet içermekteydi.

İkinci dönem, 1985-1995, dönemi olup "Nintendo dönemi” olarak etiketlenmiştir. Bilgisayarlar bu süre içinde daha karmaşık hale geldikçe, daha karmaşık grafikler de mümkün hale gelmiştir. Sonuç olarak, şiddet daha gerçekçi ve yaratıcı bir hal almıştır. Dönemin başlangıcındaki oyunlar büyük ölçüde "masum şiddet" tasviri içermekteydi. Örneğin Super Mario Brothers oyununda, karakterler üstlerine atlayarak zararlı düşmanları yenmiştir (Gentile ve Anderson, 2003).

Üçüncü ve son dönem 1995 'te başlayıp ve günümüze kadar uzanmaktadır. Bu süre zarfinda Playstation 2, Playstation 3, Xbox, Xbox 360, Nintendo Game Cube ve Nintendo Wii konsolları ortaya çıkmıştır. Olağanüstü teknolojik gelişmeler grafik gösterimi için daha büyük imkanlara yol açmış ve oyunlara sanal gerçeklik dahil olmuştur. Bu süre zarfinda, şiddet içerikli oyun temaları sektöre hakim olmuştur (Gentile ve Anderson, 2003).

Günümüzde video oyunu pazarı "Microsoft ve Xbox 360 konsolu”, "Sony ve Playstation 3 konsolu" ve "Nintendo'nun Wii konsolu” olmak üzere rakip üç donanım ve yazılım şirketi arasında bölünmüştür. Kişisel bilgisayar, aynı zamanda World of Warcraft gibi çevrimiçi tabanlı oyunların dünya genelinde 10 milyon aboneye ulaşmasına olanak tanıyan gelişmeler ile popüler bir platform olmaya devam etmektedir. Çok oyunculu oyunlar, metin tabanlı çok kullanıcılı etki alanlarından, her biri İnternet üzerinden dünya çapında bağlanan on binlerce oyuncunun bulunduğu World of Warcraft gibi daha yoğun çevrimiçi rol oyunlarının daha sürükleyici ortamlarına doğru gelişmiştir (Shaw ve Warf, 2009: 1333). Özelliklerdeki, işlemci hızlarındaki ve diğer gelişmeler oyun oynama talebinin giderek artmasına neden olmuştur (Ward, 2011: 262).

Pew Research Center'ın yapmış olduğu bir araştırmada ABD'de yaşayan yetişkinlerinin \%43'ü sık sık veya bazen bilgisayar, TV, oyun konsolu veya cep telefonu gibi taşınabilir bir cihazda video oyunları oynadıklarını belirtmiştir. Oyun oynama özellikle 13-19 yaş aralığındaki erkekler arasında popüler bir aktivitedir. Yetişkinlerin çoğunluğu özellikle de 65 yaş ve üstü katılımcılar video oyunlarının silahlı şiddete katkı sağlayan bir faktör olduğuna inanmaktadır (https://www.pewresearch.org/facttank/2018/09/17/5-facts-about-americans-and-video-games/). 2018'de 96 milyar dolar büyüklüğünde olan küresel video oyun endüstrisi (https://www.researchandmarkets.com/ research/hh9q8d/global_video?w=5) ülkemizde de popüler bir konuma sahiptir. Öyle ki Türkiye'de 2018'de oyuncu sayısının 30 milyondan fazla olduğu belirtilmektedir (https:// digitalage.com.tr/wp-content/uploads/2019/04/turkiye-oyun-sektoru-raporu-2018gaming-in-turkey-190317195319.pdf).

Yukarıda değinilen veriler oyun sektörünün gelişimini gözler önüne sermektedir. Öte yandan oyun içeriklerine yönelik eleştirilerin odağında şiddet kavramının bulunduğunu 
söylemek yanlış olmayacaktır. Bu kapsamda video oyunlarında şiddet konusuna değinmek yerinde olacaktır.

\section{Video Oyunlarında Şiddet ve Sosyal Öğrenme Teorisi}

Dünya Sağlık Örgütü (WHO, 2002: 5) şiddeti "kişinin kendisine, başka bir kişiye, bir gruba veya topluluğa yönelik ölüme, yaralanmaya, psikolojik zarara, gelişim bozukluğuna ve mahrum kalmaya yol açan ya da açma ihtimali yüksek olan fiziksel gücün ya da gücün tehdit ya da fiili olarak kasıtlı olarak kullanılması" olarak tanımlamaktır. Smith vd.'ye (1998) göre ise şiddet “inandırıcı bir fiziksel güç tehdidinin açık bir ifadesi veya bir varlığa ya da bir varlık grubuna fiziksel olarak zarar vermek amaciyla bu tür bir gücün fiili olarak kullanımıdır." Şiddet aynı zamanda varlıklara karşı görünmeyen şiddet araçlarından kaynaklanan fiziksel olarak zararlı sonuçların bazı tasvirlerini de içermektedir (aktaran Smith vd., 2003: 62-63).

Video oyunları, özellikle ebeveynlerin ve eğitimcilerin şiddet içeren oyunların saldırganlık üzerindeki etkileri ile ilgili endişelerini paylaştığı endüstriyel ülkelerde, çocukları ve ergenleri etkilemektedir (Shibuya vd., 2008: 528). Video oyunlarına yönelik öne çıkan endişelerden biri de bu oyunlardaki şiddet içeriğidir (Gunter, 1998: 19). Şiddet, video oyunlarının ilk zamanlarından beri bu oyunların bir özelliği olmuştur (Gunter, 2016: 32). Popüler video oyunlarının çoğu, başka bir karakterde yaralanmaya veya ölüme neden olan tasarlanmış dövüş veya yıkım gibi şiddet eylemleri içermektedir (Thomson ve Haninger, 2001). Smith vd.'nin (2003: 66) araştırmalarındaki örneklem kapsamında inceledikleri oyunların yaklaşık \%68'inin şiddet içerdiğini ve çocuklar için uygun olan oyunların yarısından fazlasının dakikada ortalama bir veya birden fazla şiddet eylemi içerdiğini belirlemiştir. Thomson ve Haninger (2001) çocuklar için de uygun olarak kabul edilen E kategorisindeki oyunları inceledikleri araştırmada örnekleme dahil olan oyunların \%64'ünün şiddet içerdiği sonucuna ulaşmıştır.

Video oyunu şiddetine maruz kalma ve gençler arasında ciddi saldırgan davranış arasındaki potansiyel ilişkiye yönelik üç temel görüş bulunmaktadır. İlk olarak, video oyunu şiddetine maruz kalmanın sonraki ciddi saldırganlıklar üzerinde öğrenmeye dayalı bir nedensel etkisi olduğudur. İkincisi, önceki saldırganlık düzeyi yüksek olan bireylerin sonradan video oyunu şiddetine kapılacağıdır. Üçüncüsü ise video oyunları ve saldırganlık arasında herhangi bir ilişkinin temel üçüncü değişkenlere bağlı olduğudur (Ferguson, 2011: 379).

Video oyunları ve şiddet arasındaki ilişkiye yönelik yukarıda yer alan görüşlerden ilki "sosyal öğrenme teorisi” üzerinden açıklanabilir görünmektedir. Oyunların birer kitle iletişimi içeriği olduğu düşünüldüğünde bu içerikler de reklamlar, diziler, haberler gibi ilgili içerik alıcılarına sunulmaktadır. Kitle iletişim araçlarının toplumda oynadığ 1 etkili rol nedeniyle psiko-sosyal mekanizmaları hangi sembolik iletişimin; insan düşüncesini, duygusunu ve eylemini etkilediği aracılığıyla anlamak önem taşımaktadır. Sosyal öğrenme teorisi, bu etkilerin belirleyicilerini ve mekanizmalarını incelemek için aracılı bir kavramsal çerçeve sunmaktadır (Bandura, 2001: 265). 
Sosyal öğrenme teorisi, bireyler, onların davranışları ve çevreleri arasında karşılıklı bir nedensellik olduğunu önermektedir. Bu teoriye göre davranış, gözlemlenebilir bir eylem olup davranışın performansı da beklenen olası sonuçlar tarafından belirlenmektedir. Beklentiler ise bireyin doğrudan deneyimleri tarafından şekillenmekte ya da diğerleri aracılığıyla gözlemlenen dolaylı pekiştirmeler beklentilere aracılık etmektedir (LaRose ve Eastin, 2004: 360). Teoride öz-yeterlik ve sonuç beklentisi olmak üzere iki kavram öne çıkmaktadır. Öz-yeterlik "kişinin belirli performans türlerini düzenleme ve yürütme becerisinin bir yargısıdır"; sonuç beklentisi ise "bu tür performansların olası sonuçlarına yönelik bir yargıdır" (Bandura, 1997).

Sosyal öğrenme teorisi, insan davranışlarının çoğunun doğrudan öğretilmediğini veya öğrenilmediğini, ancak bireylerin çevreleriyle etkileşim yoluyla zaman içerisinde edinildikleri üzerinde durmaktadır. Bireyler, kişisel ve dolaylı deneyimlerinden hareketle yeni bilgiler kazanmakta; çeşitli ipuçları elde etmek için birtakım modeller veya medyanın sunduğu sembolik modeller aramaktadır (Hill ve Moran, 2011: 819).

Bandura'nın sosyal öğrenme kuramı, başkalarının davranışlarını, tutumlarını ve duygusal tepkilerini gözlemlemenin ve örnek almanın önemini vurgulamaktadır. Bu kuramın altında yatan dört bileşenli bir süreç bulunmaktadır. Bunlar (Bailey, 2006: 88);

- Dikkat: Örnek alınan davranışa dikkatin verilmesi,

- Akılda tutma: Örnek alınan davranışların hatırlanması,

- Yeniden üretme: Sembolik temsillerin uygun eylemlere dönüşmesi,

- Motivasyon: Bir kişinin değer verdiği teşvik ediciler, olarak sıralanmaktadır.

Teoriye göre bir çocuğun davranışı biyolojik olarak belirlenmeyip, çocuk ile çevresi arasındaki gündelik etkileşimlerin bir sonucudur. Dolayısıyla çocuğun gördüğü, çoğu kez onun inandığı haline gelmektedir. Gündelik etkileşimler çocuğun diğer çocuklara ve ebeveynlerine yönelik gözlemlerini, ödül ya da ceza almasını, ailesini ya da öğretmenlerini taklit etmesini ve medyada gördüğü içerikleri taklit etmesini içermektedir (Sheehan, 2014: 155). Dolayısıyla modellerden rol öğrenmenin önemli olduğu sosyal öğrenme kuramının temelini taklit oluşturmaktadır (Kağıtçıbaş1, 2012: 84). Diğer taraftan sosyal öğrenme teorisinin yetişkin öğrenmesi ile de ilişkili olduğunu belirtmek gerekmektedir (Merriam vd., 2007: 289). Televizyondaki modellerin izleyicilere "bilgiyi, değerleri, bilişsel yetenekleri ve yeni davranış biçimlerini” ilettiği söylenebilir (Bandura, 2004: 78).

Bush vd. (1999: 16) ise sosyal öğrenme teorisinin "sosyalleşme araçları", "sosyal yapı değişkenleri" ve "sonuçlar" olmak üzere üç unsuru olduğunu dile getirmektedir. Araştırmacılar yürütmüş oldukları araştırma bağlamında sosyalleşme araçları arasında "aileyi, kitle iletişim araçlarını ve akranları" sıralamaktadır. Bandura (1977'den ve 1986'dan aktaran Hawkins ve Hane, 2000: 85) medyanın ve özellikle televizyonun yaygın doğasının gözlemsel öğrenmeyi önemli ölçüde artırdığını; sosyal öğrenmenin her yaşta etkili olan bir diğer kaynağının televizyon, film ve diğer görsel medya tarafından sunulan çok ve çeşitli sembolik örnek almalar olduğunu belirtmektedir. Bandura'ya göre medyadan alınan gerçekliğin imgeleri ne kadar büyükse medyanın sosyal etkisi de o kadar büyüktür. 
Birer sosyalleşme aracı olarak video oyunların sosyalleşme sürecinde oynadığ etkin rol bu oyunların model alarak öğrenmedeki işlevini somutlaştırmaktadır. Öyle ki bu oyunlardaki temsil ve betimlemeler kültürün bir yansıması olduğu gibi içeriğin alıcılarına yönelik sembolik örnek alma kalıpları da sunmaktadır. Bandura'nın (2004: 78) yukarıda da değinilen televizyondaki modellerin izleyicilere "bilgiyi, değerleri, bilişsel yetenekleri ve yeni davranış biçimlerini" ilettiği tespitinden hareketle çalışma bağlamında oyunlardaki şiddet içeriğinin sunumuna yönelik sembolik iletişimin sosyal öğrenme teorisi kapsamında insan düşüncesini, duygusunu ve eylemini etkileme potansiyeli video oyunlar ve öğrenme arasındaki ilişkiyi anlaşılır kılmaktadır. Çünkü video oyunlar da çeşitli bilgileri, kültürel-toplumsal değerleri, duygusal-bilişsel ve davranışsal bir eksende sunmakta ve model alarak öğrenmeye yönelik çeşitli kalıpları barındırmaktadır.

Dill ve Dill (1998) dijital oyunlardaki şiddetin bu oyunların etkileşimli doğasından dolayı televizyondaki ve filmlerdeki şiddetten daha zarar verici bir potansiyeli olduğunu, dijital oyunlarda oyuncuların, oyun içi saldırganlığ 1 aktif bir şekilde yönlendirdiğini dolayısıyla bu oyunlardaki saldırganlık ve şiddetin daha "katılımcı" bir karakter taşıdığını vurgulamaktadır. Video oyun oyuncuları aslında bir içerik alıcısı olmak yerine video oyun eylemlerine katılmakta ve bu eylemi bir dereceye kadar oluşturmaktadır. Şiddet içerikli bir video oyununda başarılı olmak için, oyuncuların şiddetli stratejileri tanımlamaları ve sonra seçmeleri gerekmektedir. Tekrarlanan şiddetli seçimler ise sürekli bir ödül döngüsü ile sonuçlanmaktadır (Funk vd., 2004: 24).

Anderson ve Bushman (2001: 358) yürütmüş oldukları araştırmanın sonuçlarına dayanarak şiddet içerikli video oyunlarına maruz kalmanın, kolej çağı bireyleri de dahil olmak üzere çocuklar ve gençler için bir tehdit oluşturduğunu belirtmektedir. Benzer şekilde Griffiths de (1999: 203) küçük çocuklar üzerindeki çalışmaların çoğunluğunungençlerindekilerin aksine- çocukların şiddet içeren bir video oyunu oynadıktan veya izledikten sonra daha saldırgan hale geldiğini gösterme eğiliminde olduğunu vurgulamaktadır. Şiddet içerikli oyun eylemlerini ödüllendirmek düşmanca duygu, saldırgan düşünme ve davranışı artırmaktadır. Şiddet eylemlerini ödüllendiren oyunların saldırgan düşünmeyi artırarak saldırgan davranışları artırabileceği dile getirilmektedir (Carnagey ve Anderson, 2005: 882).

Araştırmalar, şiddet içerikli video oyunları oynamanın, şiddet içermeyen video oyunlarına kıyasla daha yüksek seviyelerde saldırgan biliş, duygu, fizyolojik uyarılma ve davranışlar ürettiğini göstermektedir (Adachi ve Willoughby, 2011: 55). Carnagey vd. (2007: 495) ise yapmış oldukları çalışmada şiddet içerikli video oyununa maruz kalmanın gerçek hayattaki şiddete yönelik bir duyarsızlaşmaya da neden olabileceği sonucuna ulaşmiştır.

Araştırma nitel yaklaşımla yapılandırıldığından doğrudan video oyunları ve saldırgan davranış arasında bir ilişki olduğunu söylemek bu araştırmanın kapsamı dışında olsa da ilgili literatür, video oyunları ile saldırganlık arasındaki ilişkiyi somutlaştırmaktadır. Özellikle model alarak öğrenme sürecinde şiddet içerikli video oyunların olumsuz bir etkisinin olduğu söylenebilir. 


\section{Yöntem}

Video oyunlar analiz edilirken farklı yaklaşımlardan hareket edilmektedir. Çalışmada video oyunlar nitel içerik analizinden hareketle değerlendirilmiştir. Bu kapsamda Egenfeldt-Nielsen vd. (2013, 9-10), Salen ve Zimmerman'ın oyunlara yönelik analiz yaklaşımını beşli bir sınıflandırma biçimi içerecek şekilde uyarlamıştır. Söz konusu sınıflandırma şu şekildedir:

- Oyun: Amaç oyunun yapısını, ödülü ve oyuncunun oyun dünyasındaki temsili gibi belirli tekniklerin nasıl uygulandığını incelemektir. Temel yöntemsel yaklaşım metinsel analizdir. Teorik alt yapısını karşılaştırmalı edebiyat ve film çalışmaları oluşturur. Temel ilgi alanı tasarım seçimleri ve anlamdır.

- Oyuncular: Bu kategoriye odaklanan araştırmalar oyun oynayanların bir sosyal mekân olarak bu oyunları nasıl oynadıklarına odaklanmaktadır. Temel yöntemsel yaklaşım gözlem, görüşme ve ankettir. Sosyoloji, etnografi ve kültürel çalışmalar teorik alt yapısını oluşturur. Oyunların kullanımı ve oyun toplulukları temel ilgi alanıdır.

- Kültür: Oyunların kültürel yapı ile nasıl etkileşime geçtiği incelenir. Temel yöntemsel yaklaşım görüşmeler ve metinsel analizdir. Teorik alt yapısını kültürel çalışmalar ve sosyoloji oluşturur. Temel ilgi alanı kültürel nesneler olarak oyunlar ve medya ekolojisinin bir parçası olarak oyunlardır.

- Ontoloji: Amaç oyunların felsefi temellerini incelemektir. Temel yöntemsel yaklaşım felsefi sorgulamadır. Felsefe, kültürel tarih ve edebiyat eleştirisi teorik alt yapısını oluşturur. Oyunların ve oyun oynamanın felsefi ve mantıksal temelleri temel ilgi alanıdır.

- Metrikler: Oyuncu davranışının nicel ölçümü gibi veri odaklı tasarımlar olup kullanıcı verisine yönelik istatistiksel analizler temel yöntemsel yaklaşımdır. Teorik alt yapıyı oluşturan alan ise davranışsal psikolojidir. Temel ilgi alanı oyun tasarımıdır.

Oyunlardaki şiddet içeriğini ele alan bu araştırma yukarıdaki sınıflandırmadan oyun ve kültür boyutuna odaklanmaktadır. Araştırmanın amacı video oyunlarda şiddetin nasıl kurulduğu ve sunulduğunu ortaya koymak olduğundan araştırmada nitel içerik analizi uygulanmıştır.

Nitel içerik analizi bir materyaldeki anlamı sistematik bir şekilde tanımlama yöntemi olup sözel, görsel ve yazılı metinleri analizde kullanmaktadır (Schreirer, 2012: 1-3). Örtük anlamların analiz edildiği bu yöntem (Kuckartz, 2014: 31), oldukça sistematik ve esnek olup materyalde analiz edilecek miktarı azaltmaktadır (Schreirer, 2014: 170171). Nitel içerik analizinde yazılı veriler kullanılabileceği gibi, görsel-işitsel veriler de kullanılmaktadır. $\quad \mathrm{Bu}$ analiz yönteminde amaç, incelenen kavramın bütüncül bir resmini çizmek ve verideki bağlamsal anlamlardan hareketle detayl1, zengin ve incelikli yorumlar üretmektir (Eriksson ve Kovalainen, 2016: 120).

Devereux (2005: 116-122) içeriğin, medya endüstrileri ve medya izler kitlesi arasındaki ilişkinin merkezinde yer aldığını ve medya metinlerinin sembolik, söylemsel, çerçeveleme ile anlatı boyutlarına odaklanan nitel içerik analizinde örtük ögelerin yanı 
sıra açık ögelerin de analiz edildiğini vurgulamaktadır. Öyle ki bir metnin belirli özellikleri daha sonra sayılara dönüştürüldügüüde bile, metnin tüm okunması niteldir (Krippendorf, 2018: 16). Metnin önemli yönlerini analiz eden nitel içerik analizi metinleri izole olmuş varlıklar olarak değerlendirmemekte, üretim ve yorumlama süreci arasındaki etkileşim alanı olarak değerlendirmektedir (Pickering, 2004: 889-890).

Pozitivist yaklaşıma göre daha yorumlayıcı olan nitel içerik analizi belirli araştırma soruları belirlemeyi ve seçilen içeriği sistematik bir şekilde değerlendirmeyi gerektirmekte (Priest, 2010: 110-111) ve nitel içerik analizinde dikkat, metnin bağlamsal anlamına yöneltilmektedir (Hall, 2018: 399). Nitel içerik analizi araştırma soruları ile başlayıp metnin gözlemlenmesi ile devam etmektedir (Adler ve Clark, 2007: 375).

Video oyunları sadece metinden ibaret olmayıp karmaşık görseller de içermektedir (Wolf, 2015: 4). Adler ve Clark (2007: 376) fotoğrafların, video görüntülerin, resimlerin, çizimlerin ve haritaların incelendiği görsel analizin de bir çeşit içerik analizi olduğunu belirtmektedir. Dolayısıyla oyunlardaki görseller de yorumlanmıştır. Video oyunu, eylem / tepki ve strateji olmak üzere iki şey etrafında inşa edilmiş bir nesnedir, ancak bu çok soyut olduğundan oyunun var olmak için bir türe ihtiyacı bulunmaktadır. Bu türler klasik / beceri oyunları, aksiyon oyunları, strateji oyunları, rol yapma oyunları, simülasyon oyunları ve eğitim oyunlarını içermektedir. Görüntüler oyunda algılanan ilk şeydir ve oyun kavramını aktarmaktadır (Friedman, 2015: 293).

Nitel analizin uygulanmasında konu ile ilgili olarak daha önce yapılan çalışmalardan yararlanılmıştır. Başka bir deyişle nitel içerik analizinde veriyi değerlendirmek için tümdengelim yaklaşımı temel alınarak daha önce oluşturulmuş kodlar temel alınabileceği gibi tümevarım yaklaşımıyla yeni kodlar da belirlenebilir ya da önceki kodlar geliştirilebilir (Forman ve Damschroder, 2008: 48). Bu kapsamda oyunlardaki şiddet içeriğini yorumlamada Brand vd. (2003) ile Smith vd.'nin (2003) çalışmaları temel alınmıştır. Söz konusu çalışmalar nicel içerik analizi ile yapılandırıldığından kodlar yerine iki çalışmada da kategoriler belirlenmiştir. Brand vd.'nin (2003) araştırması doğrudan oyunlardaki şiddet içeriğine odaklanmamış olsa da özellikle oyunların betimsel olarak incelenmesinde çeşitli kategoriler sunmaktadır. Tablo 1'de bahsi geçen araştırmacıların analizde odaklandıkları kategoriler yer almaktadır.

Tablo 1. Video oyunlarda içeriğe odaklanan çalışmaların analiz kategorileri

\begin{tabular}{|c|c|}
\hline \multirow{2}{*}{ Oyunun geçtiği çevre } & $\begin{array}{l}\text { Açık alan: Şehir, orman, dağ, yol, fantastik... } \\
\text { Çevresel faktörler: Bulut, güneş, ateş, sis, yağmur... }\end{array}$ \\
\hline & Kapalı alan \\
\hline \multirow{2}{*}{ Oyun dünyasının nesneleri } & $\begin{array}{l}\text { Görünen özellikler: Binalar, 1şıklar, ağaçlar, işaretler, yollar, } \\
\text { hayvanlar, yiyecek... }\end{array}$ \\
\hline & Araç-gereçler: Taşıt, silah, müzikal alet, anahtar... \\
\hline \multirow[b]{2}{*}{$\begin{array}{l}\text { Oyun dünyasının nüfus } \\
\text { yoğunluğu }\end{array}$} & Tenha, seyrek nüfus, fazla nüfus... \\
\hline & $\begin{array}{l}\text { Ana karakterler, ikincil karakterler, hareketli bir arka plan, } \\
\text { hareketli olmayan bir arka plan... }\end{array}$ \\
\hline \multirow{2}{*}{ Karakter rolleri } & İnsan, hayvan... \\
\hline & Grup ilişkileri: Bağımsız, küçük grup... \\
\hline Şiddeti uygulayan taraf & $\begin{array}{l}\text { İnsan, robot, insani nitelikler taşıyan bir varlik } \\
\text { (anthropomorphize).... }\end{array}$ \\
\hline Şiddetin uygulandığı taraf & $\begin{array}{l}\text { Insan, robot, insanı nitelikler taşıyan bir varlık } \\
\text { (anthropomorphize)... }\end{array}$ \\
\hline Şiddet aracı & Fiziksel, silah, biçak... \\
\hline Şiddetin nedeni & $\begin{array}{l}\text { Hayatı korumak, mülkiyeti korumak, kızgınlık, misilleme, kişisel } \\
\text { kazanc. zihinsel istikrarsızlık. diŏer... }\end{array}$ \\
\hline
\end{tabular}


Amaçlı örneklem seçme yöntemi nitel içerik analizinde yaygın olarak kullanılmaktadır (Schilling, 2017: 352). Bu kapsamda toplam 10 video oyunun 24 tanıtım materyali analiz birimi olarak amaçlı bir şekilde seçilmiş ve bu oyunlarda şiddetin sunumu nitel içerik analizi yöntemi ile ortaya konmaya çalışılmıştır. Araştırma kapsamında yanıtı aranan temel sorular şunlardır:

İncelenen video oyunların tanıtımlarında hangi temalar ve çekicilik türleri öne çıkmaktadır? Video oyunların tanıtım videolarında şiddet nasıl sunulmakta ve tanıtım dili olarak nasıl kullanılmaktadır? Bu doğrultuda ilk olarak oyunlar, oyunun geçtiği çevre, oyun dünyasının nesneleri ve nüfus yoğunluğu ile karakter rolleri açısından betimlenmiştir. Oyunlara yönelik genel bir betimlemenin ardından araştırmanın temel problemi olan şiddetin oyunlardaki sunumu ortaya konmuş ve yorumlanmıştır. Yorumlamada şiddetin tarafları, aracı ve nedeni gibi kategoriler göz önünde bulundurularak oyunlardaki açık anlamlar incelenmiş ve örtük anlamlar ise yüzeye taşınarak değerlendirilmiştir. Oyunlarda yer alan metinler ve görsel unsurlar nitel yorumlamanın çatısını; Egenfeldt-Nielsen vd.'nin (2013: 9-10), Salen ve Zimmerman'ın oyunlara yönelik analiz yaklaşımını sınıflandırdıkları beşli yaklaşımdan "oyun" ve "kültür" boyutları ise şiddet içeriğini yorumlamada temel boyutları oluşturmuştur.

\section{Bulgular}

2020 yılı ve sonrasında çıkacağı açıklanan ve resmi tanıtımları yapılan son nesil AAA video oyunlar (Triple A; oyun stüdyolarınca yıllarca geliştirilen ve 60 dolar bandında satılan milyon dolarlara mal olan yüksek bütçeli oyunlar; Schultz, 2018) amaçlı olarak seçilmiş, söz konusu oyunlar reklam çekicilikleri ve şiddet temaları / sunumları itibariyle analiz edilmiştir. Tanıtım içeriklerindeki temalar, çekicilik türleri ve şiddet sunum yapıları çözümlenen oyunlar, Brand vd. (2003); Smith vd. (2003) tarafından ortaya konan analiz kategorileri üzerinden değerlendirilmiştir. IGN, WIRED, Polygon, Gamespot ve Techradar gibi en çok tıklanan oyun ve eğlence haber sitelerine göre 2020-2021 y1lları en çok beklenen AAA oyunlar arasından yargısal olarak seçilen ve farklı platformlara (Playstation, Xbox, Nintendo, PC, Stadia ve VR) çıkan 10 video oyunun tanıtım materyalleri (reveal ya da premiere olarak tanımlanan resmi teaser, trailer, gameplay formatındaki toplam 24 video) değerlendirilmektedir. Bu bağlamda seçilen oyunların listesi ve metacritic (eleştirmen ve kullanıcıların eğlence içeriklerine verdikleri ortalama puanların yayınlandığı platform) ortalama puanları Tablo 2'de ifade edilmektedir.

Tablo 2. Video oyunların "Metacritic" puanları

\begin{tabular}{|l|l|l|}
\hline Video Oyun & Meta (Eleştirmen) Puanı & Kullanıcı Puanı \\
\hline 1. Cyberpunk 2077 & $56-86^{*}$ & $35-72^{*}$ \\
\hline 2. Last of Us Part 2 & 93 & 57 \\
\hline 3. Doom Eternal & $87-88^{*}$ & $81-85^{*}$ \\
\hline 4. Watch Dogs Legion & $87-88^{*}$ & $81-87^{*}$ \\
\hline 5. Halo Infinite & - & - \\
\hline 6. Marvel's Avengers & $67-68^{*}$ & $31-54^{*}$ \\
\hline 7. Half Life Alyx & 93 & 91 \\
\hline 8. Ghost of Tsushima & 83 & 92 \\
\hline 9. Hellblade 2 & - & - \\
\hline 10. Final Fantasy VII Remake & 87 & 82 \\
\hline
\end{tabular}

*Farklı platformlara (Playstation, Xbox, Nintendo, PC) çıkan oyunlara verilen en düşük ve en yüksek değerlendirme puanları 
Tablo incelendiğinde eleştirmenlerin en yüksek puan verdiği oyunların Last of Us Part 2 ve Half Life Alyx; oyuncuların ise en yüksek puan verdiği oyunların Ghost of Tsushima ve Half Life Alyx olduğu görülmektedir. Kullanıcı puanları ile eleştirmenlerin puanlarının birbirine çok yakın olduğu oyunları ise Watch Dogs Legion, Doom Eternal ve Half Life Alyx yapımları oluşturmaktadır. Yapılan eleştiriler detaylandırıldığında değerlendirme makasının çok açıldığı Cyberpunk 2077 ile Marvel's Avengers oyunlarının performans sorunları, beklentilere karşılık verme (yaratılan hype) düzeyi ve oyun mekanikleri çerçevesinde; Last of Us Part 2 yapımının ise hikaye akışı, cinsel gerilim ve şiddet düzeyi bağlamında eleştirildiği gözlemlenmektedir. Tabloda "metaskor" olarak da betimlenen profesyonel eleştirmen puanlaması daha tutarlı ve yüksek seyrederken, kullanıcı skorlarının değişkenliği dikkat çekmektedir. Söz konusu dengesiz görüntünün "sanal linç (yapımcıyı / oyunu cezalandırma)", "fanboy davranışı (topluluk yönetimi)", "hype (tanıtımlarla yaratılan beklenti düzeyi) kültürü" gibi değişkenler çerçevesinde açıklandığı ifade edilmektedir (Subhan, 2020; Tassi, 2020; Zentler, 2020). Söz konusu tablodan hareketle oyunseverlerin metaskor ortalamasına bakarak oyun tercih ettikleri de dillendirilmektedir (Johnson, vd., 2014: 141-148). Öte yandan araştırmanın yapıldı ğ1 tarihte Halo Infinite ve Senua's Saga: Hellblade 2 oyunları piyasaya sürülmediği için söz konusu yapımlara yönelik değerlendirme bilgisi bulunmamaktadır. Bu doğrultuda araştırmaya piyasaya sürülen ve sürülmemiş olan oyunlar dahil edilerek video tanıtımlar ile metapuan ilişkisi tartışmaya açılmaktadır. Metapuanı yüksek olan yapımların, tanıtım materyallerinde yoğun bir şekilde şiddet temalı içeriklere yer vermesi şiddetin satış diline göndermede bulunabilmekte; eleştiri puanlamasında olumsuz bir kritere dönüşmediği anlaşılmaktadır.

Oyun yapımcısı ya da dağıtımcısının resmi Youtube hesaplarında paylaşılan tanıtım içerikleri bağlamında yürütülen araştırma kapsamında oyunların betimsel boyuttaki bilgilerine Tablo 3 'te yer verilmektedir. Söz konusu tabloda oyunların türü, çıkış tarihleri, çıktıkları platformlar, reyting dereceleri, yapımcı firmaları, ortalama yapım bütçeleri, tanıtım materyallerinin türü ve süresi ile tanıtım videolarının izlenme oranları bulunmaktadır.

Tablo 3. Oyunlara ait betimsel bilgiler

\begin{tabular}{|c|c|c|c|c|c|c|}
\hline Oyunlar & $\begin{array}{l}\text { Türü/Çıkış } \\
\text { Tarihi }\end{array}$ & $\begin{array}{l}\text { Platform } \\
\text { Desteği }\end{array}$ & $\begin{array}{l}\text { Reyting } \\
\text { Klasmanı }\end{array}$ & $\begin{array}{l}\text { Yapımcı } \\
\text { firma ve } \\
\text { ort. bütçe }\end{array}$ & $\begin{array}{l}\text { Tanıtım video } \\
\text { türüi/süresi }\end{array}$ & $\begin{array}{l}\text { Tanıtım video yılı/ } \\
\text { izlenme }\end{array}$ \\
\hline $\begin{array}{l}\text { Cyberpunk } \\
2077\end{array}$ & $\begin{array}{l}\text { FPS, } \\
\text { aksiyon, } \\
10.12 .2020\end{array}$ & $\begin{array}{l}\text { PC, } \\
\text { Konsollar } \\
\text { ve Stadia }\end{array}$ & $\begin{array}{l}\text { M } \\
\text { (Mature; } \\
17 \text { yaş ve } \\
\text { üzeri) }\end{array}$ & $\begin{array}{l}\text { CD Projekt } \\
\text { Red, } \\
\text { yaklaşık } 100 \\
\text { milyon \$ }\end{array}$ & $\begin{array}{l}\text { Teaser }(02.20) \\
\text { Trailer }(01.40) \\
\text { Gameplay } \\
(48.23) \\
\text { Cinematic } \\
(04.14)\end{array}$ & $\begin{array}{l}\text { 2013, } 24 \text { milyon üzeri } \\
\text { 2018, } 20 \text { milyon üzeri } \\
\text { 2018, } 22 \text { milyon üzeri } \\
\text { 2019, } 15 \text { milyon üzeri }\end{array}$ \\
\hline
\end{tabular}




\begin{tabular}{|c|c|c|c|c|c|c|}
\hline $\begin{array}{l}\text { Last of Us } \\
\text { Part II }\end{array}$ & $\begin{array}{l}\text { Aksiyon, } \\
\text { macera, } \\
19.06 .2020\end{array}$ & $\begin{array}{l}\text { PS4 ve } \\
\text { PS5 }\end{array}$ & M & $\begin{array}{l}\text { Sony, } \\
\text { Naughty } \\
\text { Dog, } \\
\text { yaklaşık } 100 \\
\text { milyon \$ }\end{array}$ & $\begin{array}{l}\text { Trailer }(04.02) \\
\text { Gameplay } \\
(11.54) \\
\text { Cinematic TV } \\
(01.21)\end{array}$ & $\begin{array}{l}\text { 2016, } 9 \text { milyon üzeri } \\
\text { 2018, } 18 \text { milyon üzeri } \\
\text { 2020, yaklaş1k } 3 \text { milyon }\end{array}$ \\
\hline $\begin{array}{l}\text { Doom } \\
\text { Eternal }\end{array}$ & $\begin{array}{l}\text { FPS, } \\
\text { aksiyon, } \\
20.03 .2020\end{array}$ & $\begin{array}{l}\text { PC, } \\
\text { Konsollar } \\
\text { ve Stadia }\end{array}$ & M & $\begin{array}{l}\text { id Software, } \\
\text { yaklaşık } 90 \\
\text { milyon \$ }\end{array}$ & $\begin{array}{l}\text { Teaser }(01.25) \\
\text { Gameplay } \\
(25.06) \\
\text { Trailer }(02.24)\end{array}$ & $\begin{array}{l}2018,15 \text { milyon üzeri } \\
2018,5 \text { milyon üzeri } \\
2020,4 \text { milyon üzeri }\end{array}$ \\
\hline $\begin{array}{l}\text { Watch } \\
\text { Dogs } \\
\text { Legion }\end{array}$ & $\begin{array}{l}\text { Aksiyon, } \\
\text { aç1k dünya, } \\
29.10 .2020\end{array}$ & $\begin{array}{l}\text { PC, } \\
\text { Konsollar } \\
\text { ve Stadia }\end{array}$ & M & $\begin{array}{l}\text { Ubisoft, } \\
\text { yaklaş1k } 68 \\
\text { milyon \$ }\end{array}$ & $\begin{array}{l}\text { Trailer }(02.57) \\
\text { Gameplay } \\
(07.47) \\
\text { Cinematic } \\
(04.07)\end{array}$ & $\begin{array}{l}\text { 2019, } 1 \text { milyon üzeri } \\
2020,1 \text { milyon üzeri } \\
\text { 2020, yaklaşık } 2.8 \\
\text { milyon }\end{array}$ \\
\hline $\begin{array}{l}\text { Halo } \\
\text { Infinite }\end{array}$ & $\begin{array}{l}\text { Aksiyon, } \\
\text { FPS, } 2021 \\
\text { (?) }\end{array}$ & PC, Xbox & $(?)$ & $\begin{array}{l}\text { Microsoft, } \\
343 \\
\text { Industries, } \\
\text { yaklaş1k } 500 \\
\text { milyon } \$\end{array}$ & $\begin{array}{l}\text { Trailer }(02.18) \\
\text { Gameplay } \\
(08.57) \\
\text { Cinematic } \\
(05.57)\end{array}$ & $\begin{array}{l}2018, \text { yaklaşık } 7.5 \text {. } \\
\text { milyon } \\
\text { 2019, yaklaş1k } 7.5 \text {. } \\
\text { milyon } \\
\text { 2019, yaklaşı1k } 1.6 \\
\text { milyon }\end{array}$ \\
\hline $\begin{array}{l}\text { Marvel's } \\
\text { Avengers }\end{array}$ & $\begin{array}{l}\text { Aksiyon, } \\
14.08 .2020\end{array}$ & $\begin{array}{l}\text { PC, } \\
\text { Konsollar } \\
\text { ve Stadia }\end{array}$ & $\begin{array}{l}\text { T (Teen; } \\
13 \text { yaş ve } \\
\text { üzeri) }\end{array}$ & $\begin{array}{l}\text { Crystal } \\
\text { Dynamics, } \\
\text { Eidos } \\
\text { Montreal, } \\
\text { yaklaşık } 190 \\
\text { milyon \$ } \\
\end{array}$ & Trailer (03.18) & 2019, 18 milyon üzeri \\
\hline $\begin{array}{l}\text { Half Life } \\
\text { Alyx }\end{array}$ & $\begin{array}{l}\text { Aksiyon, } \\
\text { FPS, } \\
23.03 .2020\end{array}$ & $\begin{array}{l}\text { VR } \\
\text { (Valve } \\
\text { Index, } \\
\text { Vive, } \\
\text { Oculus, } \\
\text { Windows } \\
\text { MR) }\end{array}$ & M & $\begin{array}{l}\text { Valve, } \\
\text { yaklaşık } 75 \\
\text { milyon \$ }\end{array}$ & $\begin{array}{l}\text { Trailer }(01.49) \\
\text { Gameplay } \\
(04.16)\end{array}$ & $\begin{array}{l}\text { 2019, yaklaşık } 11.9 \\
\text { milyon } \\
2020,2 \text { milyon üzeri }\end{array}$ \\
\hline $\begin{array}{l}\text { Ghost of } \\
\text { Tsushima }\end{array}$ & $\begin{array}{l}\text { Aksiyon, } \\
\text { aç1k dünya, } \\
17.07 .2020\end{array}$ & $\begin{array}{l}\text { PS4 ve } \\
\text { PS5 }\end{array}$ & M & $\begin{array}{l}\text { Sony, } \\
\text { Sucker } \\
\text { Punch, } \\
\text { yaklaşık } 125 \\
\text { milyon \$ }\end{array}$ & $\begin{array}{l}\text { Trailer }(02.20) \\
\text { Gameplay } \\
(08.50)\end{array}$ & $\begin{array}{l}\text { 2017, } 2.7 \text { milyon üzeri } \\
2018,5 \text { milyon üzeri }\end{array}$ \\
\hline Hellblade 2 & $\begin{array}{l}\text { Aksiyon, } \\
\text { macera, } \\
\text { korku } 2021 \\
(?)\end{array}$ & PC, Xbox & $(?)$ & $\begin{array}{l}\text { Microsoft, } \\
\text { Ninja } \\
\text { Theory, (?) }\end{array}$ & Trailer (02.07) & $\begin{array}{l}\text { 2019, yaklaşık } 1.7 \\
\text { milyon }\end{array}$ \\
\hline $\begin{array}{l}\text { Final } \\
\text { Fantasy } \\
\text { VII } \\
\text { Remake }\end{array}$ & $\begin{array}{l}\text { Aksiyon, } \\
\text { RPG, } \\
02.03 .2020\end{array}$ & $\begin{array}{l}\text { PS4 ve } \\
\text { PS5 }\end{array}$ & $\mathrm{T}$ & $\begin{array}{l}\text { Square Enix, } \\
\text { yaklaşık } 200 \\
\text { milyon \$ }\end{array}$ & $\begin{array}{l}\text { Trailer }(01.53) \\
\text { Gameplay } \\
(04.05)\end{array}$ & $\begin{array}{l}\text { 2015, yaklaşık } 16 \\
\text { milyon } \\
\text { 2019, yaklaşık } 3.5 \\
\text { milyon }\end{array}$ \\
\hline
\end{tabular}


Tablo 3'te paylaşılan veriler irdelendiğinde AAA video oyunlarda ana akım türün aksiyon-macera olduğu, konsol (PS4, PS5 ve Xbox) ağırlıklı olmak üzere çeşitli platformlara çıktıkları, yetişkinlere yönelik içeriklere sahip oldukları (Eğlence Yazılımı Derecelendirme Kurulu ESRB tarafindan "mature / M" sinıfina dahil edildikleri), resmi paylaşımlar ve / veya Google verileri çerçevesinde 100 milyon dolar ve üstü yapım maliyetine ulaştıkları görülmektedir. Tanıtım formatı olarak ise "trailer", "sinematik" ve "gameplay (oynanış)" içerikleri aracılığıyla tanıtım dilini kurguladıkları anlaşılmaktadır. İzlenme oranlarının milyonlarla ifade edilmesi ise sadece oyun / yapımcı resmi hesapları bağlamında dillendirilmekte; ikincil hesaplarda (IGN, Gamespot, Playstation, Xbox gibi) çok daha yoğun izlenmeler söz konusu olabilmektedir. İzlenme ağırlıklarında ise paylaşılan ilk tanıtımların (teaser veya trailer formatında) ile oynanış videolarının öne çıktığ görülmektedir. Özellikle oynanış videolarının içeriğe dalma (imersiyon), gerçek grafik kalitesini / atmosferi gözlemleme, oyun mekanikleri ile şiddet tonu ve dozaji ilişkisini okuma anlamında fırsat sunduğu anlaşılmaktadır. Resmi satış rakamları paylaşılmadığı için söz konusu bilginin bulunmadığı tabloda, konsol ve PC (bilgisayar) oyunlarının yanı sira bulut sistemi üzerinden oyun oynamaya imkan sağlayan Stadia ve VR türü (sanal gerçeklik cihazları) platformlar da yer almaktadır. Toplamda 80 milyonun üzerinde izlenme ile öne çıkan Cyberpunk 2077 yapımını 30 milyon üzeri izlenme oranıyla Last of Us Part II izlemektedir. Söz konusu iki oyun tanıtım içeriklerinde sundukları yoğun şiddet unsurları, derecelendirme kurulu "M" etiketi ve yasal uyarı (kan, yoğun şiddet, çıplaklık, sert / argo dil, yoğun cinsel içerik) parametreleriyle dikkat çekmektedir. Bu durum oyunların çocuklar için değil, daha ziyade yetişkinler için üretilen kültür endüstrisi ürünleri (yansıma) olduğu yorumunu hatırlatabilmektedir.

İncelenen oyunların tanıtım içeriklerindeki ana temaları, vurgulanan anahtar sözcükleri, seçilen çekicilik ögeleri, şiddet anlatısına ait bileşenleri ve yoğunlaştıkları temel şiddet türleri değerlendirildiğinde Tablo 4 kapsamında ifade edilen bulgulara ulaşılmaktadır. Şiddet anlatısı ölüm ve öldürme odaklı olduğu oyun tanıtım materyalleri, "distopya", "intikam", “istila", "isyan", "terör" ve "savaş" gibi konu başlıklarını ana tema haline getirmekte; olumsuz olarak yorumlanabilecek atmosferde anahtar sözcükler tayin edebilmektedir. Pollay'in reklam çekicilikleri bağlamında "sihir", "teknoloji", "macera", "topluluk" ve "bağımsızlık" unsurlarının yüzeye çıktığı tanıtım materyalleri, şiddet akışını söz konusu çekicilik argümanları eşliğinde desenlemektedir. Saniye saniye izlenen farklı türdeki tanıtım videoları, şiddet örgüsünü -ESRB uyarı dili paralelindekan, silah, yakın dövüş, (geleneksel ve teknolojik yöntemleri kullanan) savaş; çatışma ortamı, yıkım; yıkıntılar, ceset, tehdit ve argo dil bileşenleri çeperinde inşa etmektedir.

Tablo 4. Oyun tanıtımlarının ana temaları, çekicilik unsurları, şiddet bileșenleri ve türleri

\begin{tabular}{|l|l|l|l|l|}
\hline Oyunlar & $\begin{array}{l}\text { Ana tema/ } \\
\text { anahtar sözcükler }\end{array}$ & $\begin{array}{l}\text { Çekicilik } \\
\text { unsurları }\end{array}$ & Şiddet anlatısı/bileşenleri & Şiddet türü \\
\hline Teknoloji, sihir, & $\begin{array}{l}\text { Zevk, macera, } \\
\text { cinsellik, statü } \\
\mathbf{2 0 7 7}\end{array}$ & $\begin{array}{l}\text { Kurşun izleri, silah, yaralama, } \\
\text { argo, tehdit, kan, kesici aletler, } \\
\text { çatışma, kavga, yara(lama), } \\
\text { uzuv kesme, şok verme, ceset, } \\
\text { alev ve yanma }\end{array}$ & $\begin{array}{l}\text { Bedensel, } \\
\text { cinsel ve } \\
\text { kolektif ile } \\
\text { cürümsel } \\
\text { olmayan (kaza) } \\
\text { şiddet }\end{array}$ \\
& $\begin{array}{l}\text { Distopya, } \\
\text { siber dil, vücut } \\
\text { modifikasyonu }\end{array}$ \\
\hline
\end{tabular}




\begin{tabular}{|c|c|c|c|c|}
\hline $\begin{array}{l}\text { Last of Us } \\
\text { Part II }\end{array}$ & $\begin{array}{l}\text { Salgın, intikam, } \\
\text { yolculuk }\end{array}$ & $\begin{array}{l}\text { Macera, gençlik, } \\
\text { yabanilik, } \\
\text { cinsellik, } \\
\text { serbestlik, yakın } \\
\text { ilişki, bağımsızlık }\end{array}$ & $\begin{array}{l}\text { Kan (izleri), yaralar, cesetler, } \\
\text { çatışma, kesici aletler, enfekte } \\
\text { düşmanlar (ile kovalamaca), } \\
\text { çığlıklar, kavga, bıçaklama, } \\
\text { silahlar, eziyet görüntüleri, okla } \\
\text { öldürme, yakın dövüş, şişe ile } \\
\text { yaralama, çekiç ve pala (ile } \\
\text { yaralama ve öldürme), patlama } \\
\text { ve alevle yakma }\end{array}$ & $\begin{array}{l}\text { Bedensel ve } \\
\text { kolektif şiddet } \\
\text { (terör ve savaş) } \\
\text { ile cürümsel } \\
\text { şiddet (ölüm) }\end{array}$ \\
\hline $\begin{array}{l}\text { Doom } \\
\text { Eternal }\end{array}$ & $\begin{array}{l}\text { Cehennem, iblis, } \\
\text { istila }\end{array}$ & $\begin{array}{l}\text { Sihir, macera, } \\
\text { yabanilik, } \\
\text { gelişigüzellik }\end{array}$ & $\begin{array}{l}\text { Çığlıklar, antik mitolojik/ } \\
\text { titan canlılar, dünya yıkımı } \\
\text { ve savaşı, patlamalar, ateşli } \\
\text { silahlar, yaralama, uzuv } \\
\text { kopma, öldürme, alevler, yakın } \\
\text { dövüş ve bıçaklama/kesme } \\
\text { görüntüleri, çatışma, iskeletler, } \\
\text { cesetler, tehlikeli (sivri diş, } \\
\text { boynuz, uzun tırnak, alevli } \\
\text { uzuvlar vb.) fantastik canlılar, } \\
\text { zincir/kesici aletler/patlayıcı } \\
\text { maddeler ile öldürme }\end{array}$ & $\begin{array}{l}\text { Bedensel ve } \\
\text { kolektif şiddet } \\
\text { (terör ve savaş) } \\
\text { ile cürümsel } \\
\text { şiddet (ölüm) }\end{array}$ \\
\hline $\begin{array}{l}\text { Watch } \\
\text { Dogs } \\
\text { Legion }\end{array}$ & $\begin{array}{l}\text { Ajan, hacker, terör, } \\
\text { distopya, gelecek, } \\
\text { isyan }\end{array}$ & $\begin{array}{l}\text { Teknoloji, } \\
\text { macera, statü, } \\
\text { topluluk, } \\
\text { modernlik, } \\
\text { farklılık, bilgelik }\end{array}$ & $\begin{array}{l}\text { Patlamalar, terör saldırıları, } \\
\text { ateşli silahlar, teknolojik } \\
\text { silahlar (drone), alevler, kavga, } \\
\text { yakın dövüş (yumruk, beyzbol } \\
\text { sopası, dipçik vb.), boks } \\
\text { görüntüleri, silahlı saldırılar, } \\
\text { hackleme ve kaza görüntüleri, } \\
\text { anonim (maskeli) şiddet, } \\
\text { dükkan baskını, argo, kaçış } \\
\text { ve kovalamaca, köpek sesleri, } \\
\text { kaza görüntüleri ve kurşun } \\
\text { izleri, şehir kuşatması ve baskın } \\
\text { görüntüleri, ceset, şoklama, } \\
\text { öldürme }\end{array}$ & $\begin{array}{l}\text { Kolektif, } \\
\text { bedensel ve } \\
\text { cinsel şiddet }\end{array}$ \\
\hline $\begin{array}{l}\text { Halo } \\
\text { Infinite }\end{array}$ & $\begin{array}{l}\text { Uzay, } \\
\text { kahramanlık, } \\
\text { destan }\end{array}$ & $\begin{array}{l}\text { Macera, } \\
\text { teknoloji, } \\
\text { sihir, topluluk, } \\
\text { ahlaklilik }\end{array}$ & $\begin{array}{l}\text { Ateşli teknolojik silahlar, kaza } \\
\text { ve patlama/alev görüntüleri, } \\
\text { yara(lanma), öldürme, yakın } \\
\text { dövüş, çatışma, tehdit, yıkım }\end{array}$ & $\begin{array}{l}\text { Bedensel ve } \\
\text { kaza }\end{array}$ \\
\hline $\begin{array}{l}\text { Marvel's } \\
\text { Avengers }\end{array}$ & $\begin{array}{l}\text { Süper kahraman, } \\
\text { terör, komplo } \\
\text { teorileri }\end{array}$ & $\begin{array}{l}\text { Sihir, macera, } \\
\text { popülerlik, } \\
\text { teknoloji, } \\
\text { ahlaklılık, } \\
\text { topluluk }\end{array}$ & $\begin{array}{l}\text { Savaş uçakları, kavga, } \\
\text { patlamalar, kaza, yıkım ve } \\
\text { savaş sekansı, silahlar, şehir } \\
\text { yangını ve yıkım görüntüleri, } \\
\text { alevler }\end{array}$ & $\begin{array}{l}\text { Bedensel ve } \\
\text { kaza }\end{array}$ \\
\hline HL Alyx & Uzaylı, savaş & $\begin{array}{l}\text { Sihir, macera, } \\
\text { ahlaklılik, } \\
\text { topluluk, } \\
\text { teknoloji }\end{array}$ & $\begin{array}{l}\text { Yıkıntılar, korkutucu sesler } \\
\text { (çığlık, yaratık efektleri vb.), } \\
\text { tehlikeli/saldıran/dönüşmüş } \\
\text { fantastik canlılar, robot } \\
\text { şiddeti/hegemonyası, silahlar, } \\
\text { patlamalar, kurşunlar, yakın } \\
\text { savaş, teknolojik silahlar, tehdit, } \\
\text { cesetler, alevler, kovalamaca }\end{array}$ & $\begin{array}{l}\text { Bedensel } \\
\text { ve kaza ile } \\
\text { cürümsel şiddet } \\
\text { (ölüm) }\end{array}$ \\
\hline
\end{tabular}




\begin{tabular}{|c|c|c|c|c|}
\hline $\begin{array}{l}\text { Ghost of } \\
\text { Tsushima }\end{array}$ & $\begin{array}{l}\text { Samuray, Moğol } \\
\text { istilası, özgürlük }\end{array}$ & $\begin{array}{l}\text { Macera, topluluk, } \\
\text { geleneksellik, } \\
\text { ahlaklilik, } \\
\text { yabanilik }\end{array}$ & $\begin{array}{l}\text { Samuray savaşı, kılıç (ve } \\
\text { katana saplama/kılıçla kesme), } \\
\text { geleneksel savaş görüntüleri } \\
\text { (kılıç, mızrak ve ok ile öldürme; } \\
\text { yaralama), yakın dövüş, } \\
\text { çatışma, kan, alevler, istila, bire } \\
\text { bir ölümcül düellolar, kalkan, } \\
\text { argo, işkence }\end{array}$ & $\begin{array}{l}\text { Bedensel ve } \\
\text { kolektif şiddet } \\
\text { (istila ve savaş) } \\
\text { ile cürümsel } \\
\text { şiddet (ölüm) }\end{array}$ \\
\hline Hellblade 2 & $\begin{array}{l}\text { Mitoloji, delilik, } \\
\text { yolculuk }\end{array}$ & $\begin{array}{l}\text { Sihir, macera, } \\
\text { farklılık, } \\
\text { yabanilik, } \\
\text { bağımsızlık }\end{array}$ & $\begin{array}{l}\text { Alevler, iskeletler, kafatasları, } \\
\text { çığlıklar, ezoterik törenler, } \\
\text { kesilmiş ve asılmış kollar, } \\
\text { mitolojik/fantastik canlılar, } \\
\text { kalkan, ok, mızrak }\end{array}$ & $\begin{array}{l}\text { Bedensel ve } \\
\text { kolektif şiddet } \\
\text { (k1yım) }\end{array}$ \\
\hline $\begin{array}{l}\text { Final } \\
\text { Fantasy } \\
\text { VII } \\
\text { Remake }\end{array}$ & Distopya & $\begin{array}{l}\text { Macera, topluluk, } \\
\text { bağımsızlık }\end{array}$ & $\begin{array}{l}\text { Teknolojik silahlar, kılıç, } \\
\text { mızrak, yakın dövüş, kuşatma, } \\
\text { patlamalar, alevler, yıkıntılar, } \\
\text { kovalamaca, çatışma, fantastik } \\
\text { insansı canlılar, argo }\end{array}$ & $\begin{array}{l}\text { Bedensel ve } \\
\text { kolektif şiddet } \\
\text { (kuşatma) ile } \\
\text { cürümsel şiddet } \\
\text { (ölüm) }\end{array}$ \\
\hline
\end{tabular}

Şiddet anlatısında öne çıkan şiddet türlerini bedensel ve kolektif (topluluk ilişkileri örgüsünde) şiddet olduğu oyun tanıtımları, sahne ve sekans geçişleriyle şiddet dokusunu video geneline yaymaktadır. Söz konusu işleyiş tanıtımlarda şiddetin "satışa" kaynaklık eden bileşen olduğu savını güçlendirebilmektedir. Bire bir çatışma, yakın dövüş, birinci şahıs kamera, kan/alev/vuruş/öldürme/ses efektleri ve silah çeşitliliği gibi bileşenlerle ilerleyen anlatı kurgusu, "alternatif" gerçeklik önsözünü "gerçekçi”" modellemelerle desteklemektedir. Tanıtım videolarında ve metinlerinde vurgulanan ifadelerle; anahtar sözcüklerle şiddetin vaade dönüştüğü oyun sunumları, aşağıda örneklendirilen kare; ekran görüntüsü bağlamında şiddet anlatılarını pekiştirebilmektedir (Görsel 1). Görsel 1'de yaşanan silahlı çatışma ve kan efektleri şiddetin etkili/detaylı/sansasyonel modellenmesine örnek teşkil edebilmektedir.

Görsel 1. Cyberpunk 2077 tanıtım içeriğine ait ekran görüntüsü

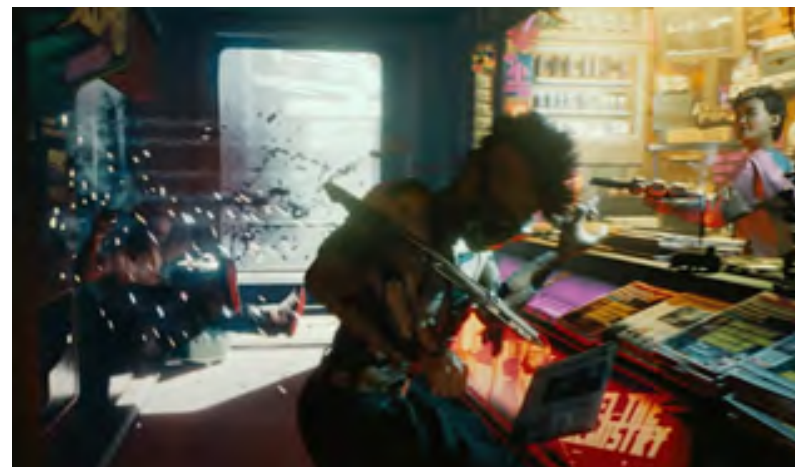

Öte yandan incelenen video oyunlarda farklı konu, tema ve atmosferler işlense de fiziksel, kolektif ve teknolojik temelli şiddet unsurlarının ön plana çıktığı, gerilim, 
pagan kültür, distopya, kurgusal / alternatif evren, birinci şahış rol yapma dinamiklerinin ağırlıkta olduğu gözlemlenmektedir. Oyun çevresi ve ana nesneleri analiz edildiğinde distopik kurguların (Londra ve Seattle gibi), fantastik evrenlerin (Midgar ve Night City gibi), ulaşılamaz alternatif gerçeklik mekanlarının (eski Tsushima, uzay veya yeryüzü cehennemi gibi) oyun seti / ortamı haline geldiği görülmektedir (Tablo 5). Söz konusu yapı, oyunların simüle deneyimleri gerçek ötesi atmosferlerde canlandırma çabasını resmedebilmektedir. Dolayısıyla şiddetin sunumu gerçekçi olsa da geçtiği ortamlar; atmosferler alternatif setlerde / dekorda gerçekleşmektedir. Bu durum oyuncuların "dijital katarsis" ihtiyaçlarını tatmin etmede şiddet eylemini aynalanmış (bire bir aktarılmış) gerçeklik yerine oyun mekaniği olarak konumlandırmalarına yardımcı olabilmektedir. Tanıtımlara yansıyan oyun nüfusunun oyun türü (açık dünya ise yaşayan; hareketli arka planla sunma, FPS-aksiyon ise tekil karakter odaklı tasarlama gibi), ortamı, mekanikleri ve tutarlığ güdümünde gerçekliğini inandırıcı kılmaktadır. Tanıtım materyallerinde gözlenen karakter rollerinde ise kadın karakterlerin erkek karakterlerle eşit düzeyde yer aldığı (özellikle ana karakterlerin kadın olduğu Last of Us Part 2 ve Hellblade 2 oyunlarında) dikkat çekmektedir. Karakter işlenişi ve işleyişi "ş̧iddet" değişkeni bağlamında okunduğunda şiddetin insana (özellikle erkeğe), robotlara, enfekte fantastik veya insani nitelikleri olan varlıklara (antropomorfizm) dönük sunulduğu ortaya çıkmaktadır. Bu durum -daha önce belirtildiği şekilde- şiddetin eylemsel boyutta gerçekliğe yakın olduğu savı beraberinde yorumlandığında, oyunların "dijital katarsis" işlevi ön plana çıkmaktadır. Bir diğer deyişle oyunlardaki şiddet tasarımı ve sunumu, gerçekliği kopyalamak yerine onu -hayatta karş1llğ1 olmayan- alternatif ortam ve taraflara yöneltmektedir.

Tablo 5. Oyun tanıtım içeriklerine ait genel kategorik bulgular

\begin{tabular}{|c|c|c|c|c|c|}
\hline Oyunlar & $\begin{array}{l}\text { Oyun çevresi ve } \\
\text { nesneleri }\end{array}$ & $\begin{array}{l}\text { Oyun } \\
\text { nüfus } \\
\text { yoğunluğu }\end{array}$ & $\begin{array}{l}\text { Karakter } \\
\text { rolleri }\end{array}$ & Şiddetin tarafları & $\begin{array}{l}\text { Şiddet araci ve } \\
\text { nedeni }\end{array}$ \\
\hline $\begin{array}{l}\text { Cyberpunk } \\
2077\end{array}$ & $\begin{array}{l}\text { Distopik evren } \\
\text { (Night City), } \\
\text { gelişmiş kurgusal } \\
\text { siber teknolojiler } \\
\text { ve silahlar }\end{array}$ & $\begin{array}{l}\text { Yoğun } \\
\text { nüfus ve } \\
\text { hareketli; } \\
\text { yaşayan } \\
\text { şehir }\end{array}$ & $\begin{array}{l}\text { İnsan (erkek } \\
\text { ve kadın } \\
\text { karakter), } \\
\text { siborg, robot, } \\
\text { bağımlı } \\
\text { yoğun ilişkili } \\
\text { roller }\end{array}$ & $\begin{array}{l}\text { İnsan, siborg, } \\
\text { robot, insani } \\
\text { nitelikleri } \\
\text { olan varliklar } \\
\text { (antropomorfizm) }\end{array}$ & $\begin{array}{l}\text { Fiziksel, silahlı, } \\
\text { kesici aletler / } \\
\text { hayatta kalma, } \\
\text { kızgınlık, misilleme, } \\
\text { güç ve diğer }\end{array}$ \\
\hline $\begin{array}{l}\text { Last of Us } \\
\text { Part II }\end{array}$ & $\begin{array}{l}\text { Post apokaliptik, } \\
\text { pandemik ve } \\
\text { derin ekolojik } \\
\text { / neo pagan } \\
\text { atmosfer } \\
\text { (Seattle), } \\
\text { bağımsız radikal } \\
\text { gruplar }\end{array}$ & $\begin{array}{l}\text { Az; tenha } \\
\text { nüfus ve } \\
\text { sakin arka } \\
\text { plan }\end{array}$ & $\begin{array}{l}\text { İnsan (kadın } \\
\text { karakterler) } \\
\text { ve enfekte } \\
\text { canlılar, } \\
\text { hayvan, } \\
\text { grupsal ve } \\
\text { bağımsız } \\
\text { roller }\end{array}$ & $\begin{array}{l}\text { İnsan ve enfekte } \\
\text { canlilar }\end{array}$ & $\begin{array}{l}\text { Fiziksel, silahlı, } \\
\text { kesici aletler / } \\
\text { hayatta kalma, } \\
\text { kızgınlık, intikam, } \\
\text { güç ve diğer }\end{array}$ \\
\hline
\end{tabular}




\begin{tabular}{|c|c|c|c|c|c|}
\hline $\begin{array}{l}\text { Doom } \\
\text { Eternal }\end{array}$ & $\begin{array}{l}\text { Alternatif } \\
\text { ve fantastik } \\
\text { gerçeklik, } \\
\text { yeryüzü } \\
\text { cehennemi, } \\
\text { alevler ve savaş } \\
\text { ortamı }\end{array}$ & $\begin{array}{l}\text { Yoğun } \\
\text { nüfus, çok } \\
\text { hareketli } \\
\text { akış }\end{array}$ & $\begin{array}{l}\text { İnsan (erkek), } \\
\text { hayvan, } \\
\text { robot, } \\
\text { bağımsız } \\
\text { (tekil) rol }\end{array}$ & $\begin{array}{l}\text { İnsan, mitolojik } \\
\text { canlılar ve } \\
\text { insani nitelikleri } \\
\text { olan varlıklar } \\
\text { (antropomorfizm) }\end{array}$ & $\begin{array}{l}\text { Fiziksel, silahlı, } \\
\text { kesici, patlayıcı } \\
\text { aletler / savaş, } \\
\text { kıgınlık, güç ve } \\
\text { diğer }\end{array}$ \\
\hline $\begin{array}{l}\text { Watch Dogs } \\
\text { Legion }\end{array}$ & $\begin{array}{l}\text { Distopik gerçeklik } \\
\text { metropolü (Lon- } \\
\text { dra), açık dünya }\end{array}$ & $\begin{array}{l}\text { Yoğun nüfus, } \\
\text { hareketli arka } \\
\text { plan }\end{array}$ & $\begin{array}{l}\text { İnsan (erkek } \\
\text { ve kadın } \\
\text { karakter), } \\
\text { hacker grubu, } \\
\text { bağımsızlık }\end{array}$ & İnsan (sivil), robot, & $\begin{array}{l}\text { Fiziksel, silahlı ve } \\
\text { teknolojik / toplu- } \\
\text { luk/üyelik bilinci ve } \\
\text { diğer }\end{array}$ \\
\hline Halo Infinite & $\begin{array}{l}\text { Uzay (doğal } \\
\text { habitat ve } \\
\text { fantastik ortam } \\
\text { tasarımları), } \\
\text { teknolojik arazi } \\
\text { aracı/silahlar ve } \\
\text { zırh }\end{array}$ & $\begin{array}{l}\text { Az; tenha } \\
\text { ve potan- } \\
\text { siyel tehdit } \\
\text { içeren nüfus }\end{array}$ & $\begin{array}{l}\text { Bağımsız } \\
\text { tekil savaşçı } \\
\text { (The Master } \\
\text { Chief, erkek } \\
\text { karakter), } \\
\text { fantastik } \\
\text { canlılar }\end{array}$ & $\begin{array}{l}\text { Fantastik ve insani } \\
\text { nitelikleri olan } \\
\text { varliklar (antropo- } \\
\text { morfizm) }\end{array}$ & $\begin{array}{l}\text { Fiziksel, silahlı ve } \\
\text { teknolojik / insanlığ } \\
\text { kurtarma }\end{array}$ \\
\hline $\begin{array}{l}\text { Marvel's } \\
\text { Avengers }\end{array}$ & $\begin{array}{l}\text { San Francisco } \\
\text { kenti, süper } \\
\text { kahraman ögeleri } \\
\text { ve teknolojileri } \\
\text { (karargah, kalkan, } \\
\text { çekiç, zırh vb.) }\end{array}$ & $\begin{array}{l}\text { Az; tenha ve } \\
\text { kurtarılmayı } \\
\text { bekleyen } \\
\text { pasif nüfus } \\
\text { arka planı }\end{array}$ & $\begin{array}{l}\text { Süper kahra- } \\
\text { manlar (Thor, } \\
\text { Iron Man } \\
\text { vb.), tekil } \\
\text { ve ortaklaşa } \\
\text { mücadele }\end{array}$ & $\begin{array}{l}\text { Kahramanlar } \\
\text { ve fantastik } \\
\text { düşmanlar }\end{array}$ & $\begin{array}{l}\text { Fiziksel, silahlı ve } \\
\text { teknolojik / insanlığ } \\
\text { kurtarma }\end{array}$ \\
\hline HL Alyx & $\begin{array}{l}\text { Alternatif, istila } \\
\text { edilmiş dünya } \\
\text { ve fantastik } \\
\text { gerçeklik ortamı, } \\
\text { distopik teknolo- } \\
\text { ji hegemonyası }\end{array}$ & $\begin{array}{l}\text { Az; tenha } \\
\text { nüfus ve } \\
\text { hareketli } \\
\text { (istila } \\
\text { odaklı) arka } \\
\text { plan }\end{array}$ & $\begin{array}{l}\text { Ortaklı (co) } \\
\text { mücadele, bi- } \\
\text { reysel tecrübe }\end{array}$ & $\begin{array}{l}\text { İnsan, teknolo- } \\
\text { jik otorite (dev } \\
\text { robotlar, üsler vb.), } \\
\text { fantastik saldırgan } \\
\text { yaratıklar }\end{array}$ & $\begin{array}{l}\text { Fiziksel, silahlı ve } \\
\text { teknolojik / hayatta } \\
\text { kalma ve diğer }\end{array}$ \\
\hline $\begin{array}{l}\text { Ghost of } \\
\text { Tsushima }\end{array}$ & $\begin{array}{l}\text { Japonya (Tsu- } \\
\text { shima adası), } \\
\text { samuray gele- } \\
\text { nekleri ve atmos- } \\
\text { feri (at, katana, } \\
\text { düello vb.), işgal } \\
\text { coğrafyası }\end{array}$ & $\begin{array}{l}\text { Seyrek ve } \\
\text { potansiyel } \\
\text { tehdit içeren } \\
\text { nüfus }\end{array}$ & $\begin{array}{l}\text { Samuray mü- } \\
\text { cadelesi ve } \\
\text { Moğol istilası }\end{array}$ & $\begin{array}{l}\text { Samuraylar, } \\
\text { Moğollar, ada } \\
\text { halkı }\end{array}$ & $\begin{array}{l}\text { Fiziksel ve silahlı } \\
\text { / özgürlük, hayatta } \\
\text { kalma ve diğer }\end{array}$ \\
\hline Hellblade 2 & $\begin{array}{l}\text { Alternatif, fan- } \\
\text { tastik, uzak ve } \\
\text { 1ssız ortam, ezo- } \\
\text { terik tören (fan- } \\
\text { tastik canlılar, } \\
\text { kemikler vb.) }\end{array}$ & $\begin{array}{l}\text { Az; tenha } \\
\text { nüfus ve } \\
\text { hareketli } \\
\text { (tören için } \\
\text { toplanan } \\
\text { çeşitli } \\
\text { canlıların } \\
\text { olduğu) } \\
\text { arka plan }\end{array}$ & $\begin{array}{l}\text { İnsan (kadın } \\
\text { karakter), } \\
\text { klan/tören } \\
\text { topluluğu, } \\
\text { devasa } \\
\text { fantastik } \\
\text { varlıklar }\end{array}$ & $\begin{array}{l}\text { İnsan ve mitolojik/ } \\
\text { fantastik/ insani } \\
\text { nitelikleri olan } \\
\text { canlilar (antropo- } \\
\text { morfizm) }\end{array}$ & $\begin{array}{l}\text { Fiziksel / hayatta } \\
\text { kalma ve güç }\end{array}$ \\
\hline
\end{tabular}




\begin{tabular}{|c|c|c|c|c|c|}
\hline $\begin{array}{l}\text { Final } \\
\text { Fantasy VII } \\
\text { Remake }\end{array}$ & $\begin{array}{l}\text { Alternatif, } \\
\text { şirketin yönettiği } \\
\text { distopik kent } \\
\text { (Midgar), } \\
\text { dev k1lıç ve } \\
\text { teknolojik } \\
\text { düsmanlar }\end{array}$ & $\begin{array}{l}\text { Seyrek ve } \\
\text { potansiyel } \\
\text { tehdit içeren } \\
\text { nüfus }\end{array}$ & $\begin{array}{l}\text { Avalanche } \\
\text { grubu, } \\
\text { bağımlı } \\
\text { üyelik rolleri }\end{array}$ & $\begin{array}{l}\text { İnsan ve otorite } \\
\text { (Shinra şirketi ) }\end{array}$ & $\begin{array}{l}\text { Fiziksel, silahlı ve } \\
\text { teknolojik / hayatta } \\
\text { kalma ve diğer }\end{array}$ \\
\hline
\end{tabular}

Medya ekolojisinin bir parçası olan video oyunlar şiddet retoriğini "kurgusal" olan nitelikte çıktıya dönüştürmektedir. Oyun tanıtımlarındaki oyun çevresi, karakter rolleri ve şiddetin tarafları incelendiğinde (Tablo 5), oyunların -tanıtım materyalleri temelindealternatif gerçeklik ve geçerlik ürettikleri sonucu çıkarsanmaktadır. Kendi gerçekliğini yaratmaya çalışan oyun dünyaları, şiddeti bu bakış açısıyla sanal hale getirebilmekte ya da meşruiyet zeminine taşıyabilmektedir. Kurgu gerçeklik ve mekânsal deneyim firsatı sunan oyunlar, dijital sanat iddialarını fiziksel, silahlı ve teknolojik desenlerde araçsallaştırmaktadır. Video oyunlarda hayatta kalma, özgürlük, topluluk yönetimi, insanlığ kurtarma gibi temel motivasyonlarla işlerlik kazanan şiddet, gerçek ötesine taşınan ortam, karakter ve düşman (şiddet hedefi) dizaynları ile ilkel ve içgüdüsel tatmin (sosyal öğrenme nihai aşaması) yaratabilmektedir. Tablo 5 'te belirtilen değişkenler bir araya getirildiğinde Görsel 2 (Doom Eternal; yeryüzü cehennem olsaydı) ve 3 (Watch Dogs Legion; 1984 distopyası Londra'y1 esir alsayd1) kapsamında resmedilen şiddet seti; stüdyosu, "eğlence" etiketiyle kabul görebilmektedir. Bu durum oyunlardaki şiddetin eylemsel karşılığını ortadan kaldırmasa da onu karikatürize ederek "oyunların şiddete meylettiği" varsayımını göğüsleyebilmektedir. Söz konusu tablo, eğlence ve iletişim değeri; metası; medyası olan oyunlara yönelik "bilinçli tüketim" ve "medya okuryazarlığı" tartışmalarını gündeme taşıyabilmektedir.

Görsel 2 ve 3. Doom Eternal ve Watch Dogs Legion oyunlarının tanıtımlarından alınan kareler
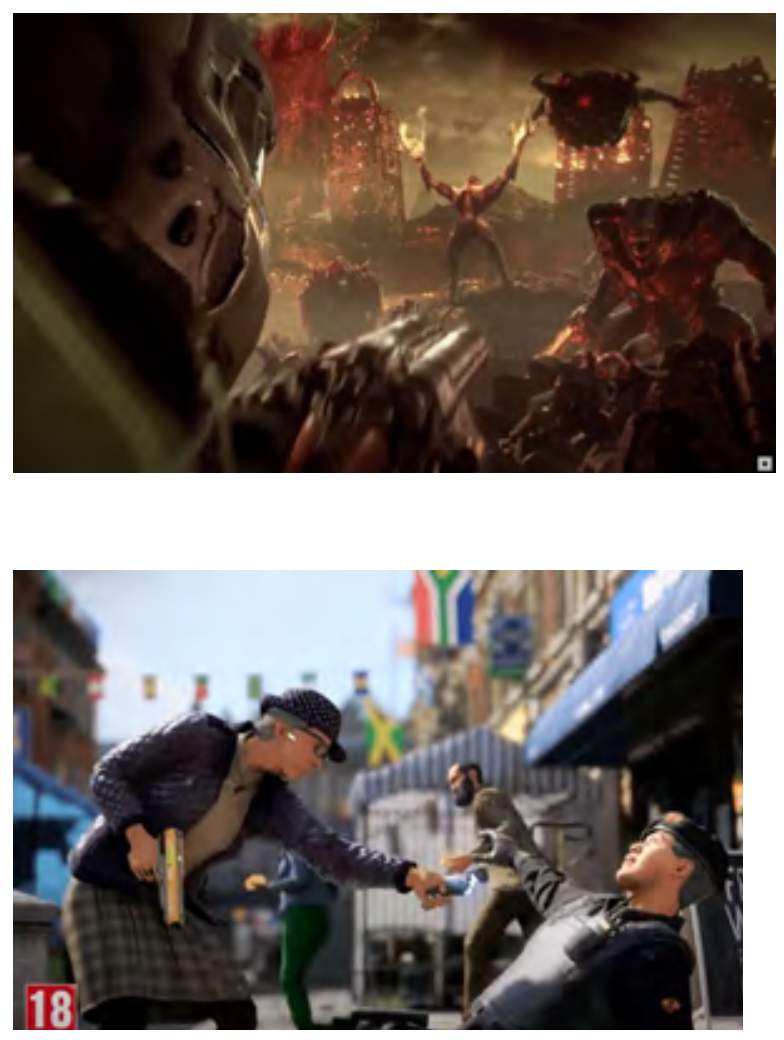
Tablo 5'e yönelik ifade edilenler doğrultusunda oyunlardaki şiddetin, oyun türü, atmosferi, şiddet kapsamı ve tasarımı eşliğinde değerlendirilmesi gereği ortaya çıkmaktadır. Bu bağlamda Last of Us Part 2, Ghost of Tsushima ve Cyberpunk 2077 gibi (gerçekçi) eylemsel şiddet içeren yapımlarda inşa edilen şiddet anlatısıyla, Marvel's Avengers ve Doom Eternal gibi tamamen fantastik; gerçek ötesi evrenler aracılığıyla sunulan şiddet icrası arasında farklar bulunmaktadır. Sürrealist bir şekilde iblis avını işleyen Doom Eternal (Görsel 2) ile mizahi çekicilikle çerçevelenen Watch Dogs Legion (Görsel 3) örneklerindeki "şiddet” söz konusu farklı değerlendirme gereksinimini gözler önüne sermektedir. Bu bağlamda çizgi film grafikler ve eğlence odaklı şiddeti işleyen oyunla (Fortnite gibi) simülasyon şeklinde şiddeti tasarlayan; gerçeğe yakınlaştıran oyun (Last of Us Part 2 gibi) arasındaki farkın altını çizmek gerekmektedir. Söz konusu vurgu beraberinde video oyunların bir "eğlence" ürünü olduğu -özellikle pandemi şartlarındafenomenal dünyanın sıkıcılığını; sıradanlığını kırmak; aşmak için tüketildiğini belirtmek anlam taşımaktadır.

Dijital sanat, medya formu, teknolojik anlat1, kültür göstergesi, e-spor gibi değerlendirmeler bağlamında deneyim değeri olan video oyunlar, literatür başlığında ifade edildiği üzere ortalama \%68 düzeyinde şiddet içerebilmektedir. Söz konusu oransal işleyiş araştırmanın örneklemi kapsamında da geçerli görünmekte; oyun tanıtım dili şiddet bileşenleri temelinde harekete geçmektedir. Dünyayı aynalayan ya da popüler gündem başlıklarını (hack, cinsiyet eşitliği, siborg, süper kahraman temaları gibi) oyuna dönüştüren veya oyun içeriklerine yediren sektör, şiddet çağrışımlarını farklı tanıtım formatlarında (teaser, trailer, gameplay gibi) vitrine taşımaktadır. Dolayısıyla oyuncularla (hedef kitle) oyun geliştirici firmalar (kaynak) arasında "gizil bir toplumsal sözleşme” gibi karşılıklı beklentiler (eğlence-satış) tatmin edilebilmektedir. Öte yandan söz konusu oyun ve şiddet ilişkisinin saldırganlığa dönüşüp dönüşmediği tartışması Ferguson'un (2011: 379) dile getirdiği “üçüncü” değişkenler (kişilik, demografi, psikografik değişkenler gibi) çerçevesinde okunabilir görünmektedir.

Şiddeti çağıran; çağrıştıran, gerilim duygusunu atmosfere yayan, şiddet altyapısını fantastik ögeler (antropomorfizm, distopya, hayali teknolojik silahlar gibi) temelinde sıradanlaştırabilen, teknolojik gelişim sayesinde karakter tasarımlarını daha inandırıcı yapabilen, anlatı / ikna gücünü şiddet dokusuyla pekiştiren ve bu yönüyle kendi tutarlı; kapsül gerçeklik algısını metalaştıran yeni nesil oyunlar, tanıtım materyallerinde seçtiği çarpıc1; durdurucu etkiye sahip şiddet anlarıyla daha akılda kalıcı etki yaratabilmektedir. Bu doğrultuda tanıtım içeriklerinde seçilen görüntüler yoğun şiddet ve gerilim anlarından oluşabilmektedir. Atari'den PS5 ve Xbox Series X veya Nvidia 3090'a kadar gerçeklik hissi grafiksel boyutta artan ve simülasyon yönü / deneyim değeri güçlenen oyunlar, reklamın ana işlevlerinden biri olan "dikkat çekme (sosyal öğrenme eşik aşaması)" adına şiddeti yüzeye çıkarabilmektedir. İncelenen yüksek bütçeli oyunlarda da söz konusu pratiğin devreye sokulduğu ve şiddetin psikolojik anlamının bir şekilde rasyonelleştirildiği; gerekçelendirildiği mizansenler göze çarpmaktadır.

İnandırıcı fiziksel güç ve tehdit duygusu temelinde tanımlanan "şiddet" kavramı, yeni medya teknolojilerinin sunduğu imkanlar dahilinde video oyunlarda piksel gücü, 4K çözünürlük, 3D ses, 60-120 fps (saniye başına düşen kare sayısı) gibi başarımlarla 
güçlü bir görsel-işitsel şölene dönüşebilmektedir. Bu bağlamda kitle iletişim objesi olan video oyunlar -özellikle oynanış (gameplay) videolarında görülen şekilde- ideal oynama; deneyimleme rehberi olarak şiddeti meşrulaştırmaktadır. Oynanış videolarında sunulan şiddet varyasyonları potansiyel tüketicilere; oyun severlere "oyun kullanım rehberi" şeklinde tanıtılmakta; oyunun etkileşim gücünü; tepkime yeteneğini şiddet temelinde tasvir etmektedir. Sosyal öğrenme bağlamında "dolaylı pekiştireç" olarak betimlenebilecek bu durum, öz yeterlik (oyuncunun yaralama/öldürme çeşitliliği, olanağ1 ve yargısı) ile sonuç beklentisi (elindeki kurgusal evrene yön verme; hükmetme gücü) arasındaki ilişkiyi şiddet olgusu; pratiği odağında hayata geçirebilmektedir. Şiddeti doğrudan deneyimleme ve oyuncu eliyle sahneleme imkanı veren video oyunlar, gündelik etkileşim aracı olarak (oyun içeriği ve tanıtım materyalleri üzerinden) maruz kalınan şiddeti "taklit" etmeye zemin hazırlayabilmektedir. Sosyal öğrenme kuramının özünde yer alan "taklit”, oyunların sahip olduğu hedef kitle yelpazesi düşünüldüğünde -özellikle çocuklar ve psikolojik rahatsızlıkları olan bireyler bağlamında- kritik önem taşıyabilmektedir.

Öte yandan online / multiplayer buluşmalarla "sosyalleşme aracı" da olabilen video oyunlar, özellikle çocukların / gençlerin akranları arasındaki şiddet dokulu oynanış senaryolarını "gözlemsel öğrenme" bağlamında gündeme getirebilmektedir. Oyuncular arasında yayılan söz konusu "sembolik örnek almalar" oyunlarda sunulan gerçekçi imgeleri sosyal etkiye dönüştürebilmektedir. Yeni nesil oyunların simülasyon, etkileşim, görsel ve anlatım gücü bir araya geldiğinde oyun severlerin eğlence anlayışlarını öğrenme modeline dönüştürme olasılıkları artabilmektedir. Bu bağlamda etkileşimli doğası ile video oyunlar, kullanıcıları “ödül döngüsü” içinde şiddet eylemlerini yöneten kat1lımc1lar haline getirebilmektedir. Carnagey vd., (2007) ile Adachi ve Willoughby (2011) referanslarının işaret ettiği gibi şiddet dokulu bu tür "uyarılma" gerçek hayattaki şiddete yönelik duyarsızlaşma olasılığını da tekrar düşündürmektedir.

\section{Sonuç ve Tartışma}

Çalışmanın amacı oyunlarla şiddet davranışı arasındaki ilişkiyi araştırmak değil, oyunların tanıtımlarındaki şiddet temasını ve sunumunu sorgulamaktır. $\mathrm{Bu}$ sorgu sonrasında belirtilen örneklem çerçevesinde durum tespiti ve ilgili literatür doğrultusunda değerlendirmeler yapılarak oyun-tanıtım-şiddet ilişkisi tartışılmaktadır. Araştırma kapsamında en çok beklenen yüksek bütçeli (triple A) video oyunlar yargısal örneklem bağlamında seçilmiş ve resmi tanıtım materyalleri (teaser, trailer, gameplay formatında videoları) içerdikleri şiddet bileşenleri odağında analiz edilmiştir. Bu bağlamda araştırmaya dahil edilen 10 video oyun (Cyberpunk 2077, Last of Us Part 2, Doom Eternal, Watch Dogs Legion, Halo Infinite, Marvel's Avengers, Half Life Alyx, Ghost of Tsushima, Hellblade 2 ve Final Fantasy VII Remake) sundukları toplam 24 tanıtım içeriğiyle araştırmaya konu edilmektedir.

Farklı formatta tanıtım materyalleri betimsel, kategorik ve bağlamsal çerçevede irdelenen oyunlar, medya görünürlüğünü şiddet bileşenleri temelinde öne çıkarabilmektedir. "Betimsel" değerlendirme sonrasında aksiyon-macera türü oyunların popüler hale geldiği, oyunların ana hedef kitlesinin yetişkinler (ESRB tarafından "mature 
/ M" sınıfında değerlendirildikleri) olduğu, konsollar başta olmak üzere çok çeşitli platformlara çıktıkları, yapım maliyetlerinin 100 milyon dolar düzeyinde seyrettiği, daha çok "trailer" ve "gameplay" formatlarında tanıtıldıkları ve izlendikleri anlaşılmaktadır.

Brand vd. (2003) ile Smith vd. (2003) tarafindan ifade edilen "kategorik" analiz bağlamında ise video oyunların yaralama ve öldürme temelinde şiddet anlatısını kurguladıkları gözlemlenmektedir. "Distopya", "intikam", "istila", "isyan", "terör" ve "savaş" gibi ana temaların egemen olduğu video oyun tanıtımları, "sihir", "teknoloji”, "macera", "topluluk" ve "bağımsızlık" çekicilikleri odağında reklam dilini yüzeye taşıyabilmektedir. Kan, silah, yakın dövüş, (geleneksel ve teknolojik yöntemleri kullanan) savaş; çatışma ortamı, yıkım; yıkıntılar, ceset, tehdit ve argo dil bileşenleri çerçevesinde şiddet örgüsünü koyultan oyun tanıtım içerikleri, bedensel ve kolektif şiddet türüne daha yakın görünmektedir. Birinci şahıs kamera, yaralama/öldürme/silah çeşitliliği, yakın ve bire bir dövüş sahneleriyle dikkat çeken tanıtımlar, "distopya", "kurgusal/alternatif evren", "gerilim", “(neo)pagan kültür", "birinci şahış rol yapma" ve "teknolojik donanım" dinamiklerine ağırlık vermektedir. İncelenen içeriklerde şiddetin sunumu -yeni nesil teknolojiler sayesinde- gerçekçi olsa da hikaye akışı alternatif ve gerçek ötesi atmosferde vücut bulmaktadır.

Söz konusu betimsel ve kategorik değerlendirme bağlamında oyun nüfus yoğunluğunun oyun türü, konusu ve atmosferi çerçevesinde (açı dünya yoğun nüfus ile FPS-aksiyon türü ise tekil karakter odağında) desenlendiği görülmektedir. Kadın karakterlere erkek karakterler kadar yer verildiği video oyunlar, şiddetin taraflarını insan ve insani nitelikleri olan varlıklar (antropomorfizm) çatışmasından hareketle tayin etmektedir. "Hayatta kalma", "özgürlük", "topluluk yönetimi” ve "insanlığ kurtarma" gerekçelerinin şiddet anlatısına kaynaklık ettiği oyun tanıtım içerikleri, şiddeti "karikatürize" ederek eğlence işlevini meşrulaştırabilmektedir. Video oyunlarda fiziksel ve hayali teknolojiler ile donatılmış silahlar temelinde gerçekleşen şiddet eylemleri, gerçek dünyanın popüler gündem başlıklarını (hack, siborg, süper kahraman temaları gibi) ve gerçekleşmesi olanaklı olmayan kurgu dünyaları (yeryüzü cehennemi, uzay seti gibi) oyuna dönüştürmektedir.

Satış dili, dikkat çekme işlevi, dijital katarsis (psikolojik deşarj) atfı, etkileşim değeri, mekanik çeşitliliği gibi motivasyonlarla şiddeti sunumun odağı haline getiren video oyunlar, ölüm ve öldürme odaklı anlatıyı pratiğe dökmektedir. Medya görünürlüğü ve viral yayılımdan hareketle oyun tanıtımlarında satan bir araç olarak şiddetin sunuma yedirildiği hatta Last of Us Part 2, Doom Eternal, Cyberpunk 2077 gibi kimi oyunlarda ana unsur haline geldiği gözlemlenmektedir. Kurgusal ve alternatif evren tasarımıyla şiddetin eylemsel yönünü ikincil öneme; dolaylı anlatıya indirgeyen yapımlar, teknik başarımı sayesinde inandırıcılık yönünü koyultmaktadır. Özellikle gameplay videolarında görülen "ideal oynama rehberi” şiddeti sıradanlaştırabilmekte, öz yeterlik (oyuncunun yaralama/öldürme çeşitliliği, olanağı ve yargısı) ile sonuç beklentisi (elindeki kurgusal evrene yön verme; hükmetme gücü) arasında bağ kurmaya yardımcı olabilmektedir. Bu bağlamda yönlendirilen oyuncular, şiddeti taklit edebilmekte, yeni nesil oyunların "dijital katarsis" yönünü -online/multiplayer modlar eşliğinde- sosyal ve işlevsel k1labilmektedir. Bu durum sosyal medya konusunda tartışılan "radikalleşme" ve "anonim kimliğe teşvik" 
eleştirilerini online oyunlara da taşıyabilmektedir.

Öte yandan video oyunlar kültür endüstrisinin yeni nesil ürünleri olarak sinema ve müzik sektörlerinin toplamından daha değerli hale gelmekte; dijital dilin popülerliğini her geçen gün artırmaktadır (Witkowski, 2021). Kapital ve dijital zaman geçirme arac1 olan video oyunlar, endüstriler arası yöndeşmenin aracı haline gelebilmektedir. Oyundan sinema veya diziye uyarlanan birçok oyun (Final Fantasy, Last of Us, Witcher gibi) içerdiği şiddet örgüsü ve sunumu ile tanıtım kabiliyetini artırabilmektedir. Bu bağlamda cosplay yarışmalarının düzenlendiği, oyunların koleksiyon sürümlerinin açık artırmaya sunulduğu, oyunları ilk alanlardan olmak için günler öncesinden sıraya girildiği veya milyonlarca ön siparişin oluşturulduğu, oyun tanıtımlarının ürünün; oyunun kendisinden daha çok heyecan; hype yaratabildiği, e-spor etkinliklerine katılmak için onlarca dolar ödendiği günümüz oyun dünyası, kültürel bir fenomen olarak dikkat çekmektedir. Söz konusu kültür atfı, oyun yapımcılarının sosyal öğrenme aracı olarak şiddeti sorumlulukla tasarlama gereğine gönderme içerebilmektedir.

Yeni nesil medya olarak video oyunlar, TV gibi gözlemsel ve dolaylı öğrenme potansiyeli içermekte ve sosyal öğrenme teorisi bağlamında sembolik rol modeller sunabilmektedir. Söz konusu sunumun içerisinde şiddet eylemlerinin yoğun olması video oyunların genel algisinı -Thomson ve Haninger (2001) ile Smith vd. (2003) çalışmalarında olduğu gibi- olumsuz etkileyebilmektedir. Bandura'nın ifade ettiği gerçeklik imgesinin büyüklüğü ile sosyal etkinin doğru orantılı ilişkisi "oyunların şiddete yönelttiği” tartışmasını cesaretlendirebilmektedir. Ayrıca şiddetin ödül döngüsüne dönüşmesi ve gençlerin davranışları üzerinde tehdit (saldırganlık eğilimi) oluşturabilmesi durumu (Griffiths, 1999: 203; Anderson 2001: 358; Funk vd., 2004: 24; Carnagey ve Anderson, 2005: 882; Carnagey vd., 2007: 495; Adachi ve Willoughby, 2011: 55) oyun sunumlarındaki şiddetin "satış" gerekçesini okumak adına önem taşımaktadır. Bu bağlamda psikolojik tatmin boyutu olan şiddetin bir duygusal; irrasyonel çekicilik olarak video oyun tanıtımlarda neden tema olarak tercih edildiği anlaşılabilmektedir.

Deneyim ekonomisi ve deneyim değeri kavramları bağlamında etkileşimli bir eğlence formu olan video oyunlar, insan davranışlarının çoğunun doğrudan öğretilmediği ya da öğrenilmediğini savlayan sosyal öğrenme teorisi bağlamında "dolaylı bir öğretici" şeklinde konumlanabilmektedir. Bu doğrultuda oyunlardaki şiddet içerikleri ve oyunların şiddet temalı tanıtımları söz konusu dolaylı etkiye aracılık edebilmektedir. Ancak bu etki uzun dönemli davranışsal araştırma ile ölçülebilecek bir araştırmanın konusu olarak öne çıkmaktadır. Bu çalışmada oyun tanıtımlarındaki şiddet yoğun içeriğin bu etkinin sonucu olabileceği çıkarımı yapılabilmektedir. Çünkü bir medya içeriği olarak video oyunlar, insan davranışlarına yönelik sembolik modeller içermektedir.

Dill ve Dill'in (1998) oyunların etkileşimli ve katılımcı yapısı nedeniyle televizyondaki ve filmlerdeki şiddetten daha zarar verici bir potansiyel barındırabileceği iddiası, yeni nesil teknolojilerle oyunlarda şiddet tasarımının daha gerçekçi ve güçlü şekilde sunulabilmesi bağlamında tekrar sorgulanabilmektedir. Bu sorgulama yeni nesillerin; toplumların oyunlara alışması, oyunlardaki alternatif gerçekliğe; şiddete bağışıklık kazanması ve oyunları artık birer "eğlence metası" olarak sıradanlaştırması gibi durumlar 
eşliğinde de tartışılabilir. Sıralanan değişkenler çerçevesinde teknolojiye yatkın yeni nesil toplumların -eski nesil bireylerden; topluluklardan farklı olarak- oyunlarla şiddet davranış1 arasındaki sınırı çoktan çizdiği varsayımı desteklenebilmektedir. Öte yandan yeni nesil oyun sunumlarında / tanıtımlarında şiddet ağırlıklı̈ ögelerön plana çıkmaktadır. Söz konusu durum, motivasyon ve davranış ilişkisini doğrulamak yerine durum tespiti yapmak adına değer atfetmektedir. Dolayısıyla bu çalışma kapsamında oyunların davranışsal olarak oyuncuları şiddete teşvik ettiği iddiası bilimsel anlamda temelsiz kalabilmekte ancak oyun tanıtımlarının şiddet temalı olduğu tespiti dillendirilebilmektedir. Şiddet "satış" artırıcı bir irrasyonel/duygusal çekici öge olarak görev almakta, insan içgüdüsünün tezahürü ve dijital katarsis mekanizması olarak rol üstlenebilmektedir.

\section{Kaynaklar}

Adachi, P. J. and Willoughby, T. (2011). The effect of violent video games on aggression: Is it more than just the violence?. Aggression and Violent Behavior, 16(1), $55-62$.

Adler, E. and Clark, R. (2007). How it's done: An invitation to social research. Belmont, CA: Thomson Wadsworth.

Anderson, C. A. and Bushman, B. J. (2001). Effects of violent video games on aggressive behavior, aggressive cognition, aggressive affect, physiological arousal, and prosocial behavior: A meta-analytic review of the scientific literature. Psychological Science, 12(5), 353-359.

Bailey, A. A. (2006). A year in the life of the African-American male in advertising: A content analysis. Journal of Advertising, 35(1), 83-104.

Bandura, A. (1997). Self-efficacy: The exercise of control. New York: Freeman.

Bandura, A. (2001). Social cognitive theory of mass communication. Media Psychology, 3, 265-299.

Bandura, A. (2004). Social cognitive theory for personal and social change by enabling media. In A. Singhal, M. J. Cody, E. M. Rogers and M. Sabido (Eds.), Entertainment-education and social change: History, research, and practice (pp. 75-96). Mahwah, NJ: Lawrence Erlbaum.

Berger, A. A. (2002). Video games: A popular culture phenomenon. New Brunswick, NJ: Transaction Publishers.

Brand, J. , Knight, S. and Majewski, J. (2003). The diverse worlds of computer games: A content analysis of spaces, populations, styles, and narratives. In M. Copier and J. Raessens (Eds.), Level up. Digital Games Research Conference. Utrecht: Universiteit Utrecht \& Digital Games Research Association.

Bush, A. J., Smith, R. and Martin, C. (1999). The influence of consumer socialization variables on attitude toward advertising: A comparison of African-Americans and Caucasians. Journal of Advertising, 28(3), 13-24. 
Carnagey, N. L. and Anderson, C. A. (2005). The effects of reward and punishment in violent video games on aggressive affect, cognition, and behavior. Psychological Science, 16(11), 882-889.

Carnagey, N. L., Anderson, C. A. and Bushman, B. J. (2007). The effect of video game violence on physiological desensitization to real-life violence. Journal of Experimental Social Psychology, 43(3), 489-496.

Crawford, G. (2012). Online gaming. Abingdon, Oxon: Routledge.

Devereux, E. (2005). Understanding the media. London: Sage.

Dill, K. E. and Dill, J. C. (1998). Video game violence: A review of the empirical literature. Aggression and Violent Behavior, 3(4), 407-428.

Egenfeldt-Nielsen, S., Smith, J. H. and Tosca, S. P. (2013). Understanding video games: The essential introduction. New York: Routledge.

Eriksson, P. and Kovalainen, A. (2016). Qualitative methods in business research: A practical guide to social research. London: Sage.

Ferguson, C. J. (2011). Video games and youth violence: A prospective analysis in adolescents. Journal of Youth and Adolescence, 40(4), 377-391.

Forman, J. and Damschroder, L. (2008). Qualitative content analysis. In L. Jacoby and L. A. Siminoff(Eds.), Empirical methods for Bioethics: A primer (pp. 39-62). Oxford, UK: Elsevier.

Friedman, A. (2015). The role of visual design in game design. Games and Culture, 10(3), 291-305.

Funk, J. B., Baldacci, H. B., Pasold, T. and Baumgardner, J. (2004). Violence exposure in real-life, video games, television, movies, and the internet: is there desensitization?. Journal of Adolescence, 27(1), 23-39.

Gentile, D. A. and Anderson, C. A. (2003). Violent video games: The newest media violence hazard. In D. A. Gentile (Ed.), Media violence and children. Westport, CT: Praeger Publishing.

Griffiths, M. (1999). Violent video games and aggression: A review of the literature. Aggression and Violent Behavior, 4(2), 203-212.

Gunter, B. (1998). The effects of video games on children: The myth unmasked. Sheffield: Sheffield Academic Press.

Gunter, B. (2016). Does playing video games make players more violent? London: Palgrave Macmillan.

Hall, C. M. (2018). Quantitative and qualitative content analysis. In. R. Nunkoo (Ed.), Handbook of research methods for tourism and hospitality management (pp. 395406). Cheltenham, UK: Edward Elgar Publishing. 
Hawkins, K. and Hane, A. C. (2000). Adolescents' perceptions of print cigarette advertising: A case for counter advertising. Journal of Health Communication, 5(1), 8396

Hill, R., P. and Moran, N. (2011). Social marketing meets interactive media: Lessons for the advertising community. International Journal of Advertising, 30(5), 815-838.

Iwatani, T. (2015). Foreword. In M. J. P. Wolf (Ed.), Video games around the world (pp. ix-xiv) Massachusetts: MIT Press.

Johnson, D., Watling, C., Gardner, J. and Nacke, L. E. (2014). The edge of glory: The relationship between metacritic scores and player experience. In Proceedings of the First ACM SIGCHI Annual Symposium on Computer-Human Interaction in Play, ACM, 141150 .

Kağıtçıbaşı, Ç. (2012). Benlik, aile ve insan gelişimi: Kültürel psikoloji. İstanbul: Koç Üniversitesi Yayınları.

Krippendorff, K. (2018). Content analysis: An introduction to its methodology. Thousand Oaks, CA: Sage.

Kuckartz, U. (2014). Qualitative text analysis: A guide to methods, practice and using software. London: Sage.

Kucklich, J. (2006). Literary theory and digital games. In J. Rutter and J. Bryce (Eds.), Understanding digital games (pp. 95-111). London, England: Sage.

Larose, R. and Eastin, M., S. (2004). A social cognitive theory of Internet uses and gratifications: Toward a new model of media attendance. Journal of Broadcasting \& Electronic Media, 48(3), 358-377.

Merriam, S. B., Caffarella, R. S. and Baumgartner, L. M. (2007). Learning in adulthood: A comprehensive guide. USA: John Wiley \& Sons.

Murray, S. (2018). On video games: The visual politics of race, gender and space. New York: IB Tauris.

Pickering, M. (2004). Qualitative content analysis. In M. Lewis-Beck, A. Bryman and T. F. Liao (Eds.), The SAGE encyclopedia of social science research methods volume 1 (pp. 889-890). Thousans Oaks, CA: Sage.

Priest, S. H. (2010). Doing media research: An introduction. Thousans Oaks, CA: Sage.

Przybylski, A. K., Ryan, R. M. and Rigby, C. S. (2009). The motivating role of violence in video games. Personality and Social Psychology Bulletin, 35(2), 243-259.

Schilling, J. (2017). Qualitative content analysis in leadership research: principles, process and application. In B. Schyns, R. J. Hall and P. Neves (Eds.), Handbook of methods in leadership research (pp. 349-371). Cheltenham, UK: Edward Elgar Publishing. 
Schreier, M. (2012). Qualitative content analysis in practice. London: Sage.

Schreier, M. (2014). Qualitative content analysis. In U. Flick (Ed.), The SAGE handbook of qualitative data analysis (pp. 170-183). London: Sage.

Schultz, W. (2018). What is a AAA video game? https://www.thoughtco.com/whatis-aaa-game-1393920. Erişim Tarihi: 22 Mart 2021.

Shaw, I. G. R. and Warf, B. (2009). Worlds of affect: Virtual geographies of video games. Environment and Planning A, 41(6), 1332-1343.

Sheehan, Kim, B. (2014). Controversies in contemporary advertising. USA: Sage Publications.

Shibuya, A., Sakamoto, A., Ihori, N. and Yukawa, S. (2008). The effects of the presence and contexts of video game violence on children: A longitudinal study in Japan. Simulation \& Gaming, 39(4), 528-539.

Smith, S. L., Lachlan, K. and Tamborini, R. (2003). Popular video games: Quantifying the presentation of violence and its context. Journal of Broadcasting \& Electronic Media, 47(1), 58-76.

Subhan, I. (2020). What 'The Last of Us Part II' tells us about Metacritic. Erişim Tarihi: 24 Mart 2021.

Tassi, P. (2020). https://www.forbes.com/sites/paultassi/2020/06/21/the-last-ofus-part-2-is-getting-predictably-user-score-bombed-on-metacritic/?sh=3da0f8455c 25 . Erişim Tarihi: 22 Mart 2021.

Thomson, K. M. and Haninger, K. (2001). Violence in e-rated video games. Journal of American Medical Association, 286(5), 591-598.

Ward, M. R. (2011). Video games and crime. Contemporary Economic Policy, 29(2), 261-273.

Witkowski, (2021). Videogames are a bigger industry than movies and North American sports combined, thanks to the pandemic. https://www.marketwatch.com/ story/videogames-are-a-bigger-industry-than-sports-and-movies-combined-thanks-tothe-pandemic-11608654990. Erişim Tarihi: 20 Mart 2021.

Wolf, M. J. P. (2015). Introduction. In M. J. P. Wolf (Ed.), video games around the world (pp. 3-16). Massachusetts: MIT Press.

World Health Organization (2002). World health report 2002: Reducing risk, promoting healthy life. Geneva.

Zentler, R. (2020). Game on: Metacritic change hinders consumer reviews. Erişim Tarihi: 20 Mart 2021. 
https://digitalage.com.tr/wp-content/uploads/2019/04/turkiye-oyun-sektoruraporu-2018-gaming-in-turkey-190317195319.pdf. Erişim Tarihi: 25 Ocak 2021.

https://www.pewresearch.org/fact-tank/2018/09/17/5-facts-about-americans-andvideo-games/. Erişim Tarihi: 25 Ocak 2021.

https://www.researchandmarkets.com/research/hh9q8d/global_video?w=5. Erişim Tarihi: 25 Ocak 2021.

Araştırmacı Katkı Oranı: Araştırmacılar çalışmaya eşit oranda katkı sunmuştur.

Destekleyen Kurum/Kuruluşlar: Herhangi bir kurum/kuruluştan destek alınmamıştır.

Çıkar Çatışması: Herhangi bir çıkar çatışması bulunmamaktadır. 